\title{
A Contribuição da Filosofia da Religião para as Ciências da Religião: Impressões Gerais
}

\author{
Luís H. Dreher*
}

\begin{abstract}
RESUMO
O texto a seguir pretende ser mais um contributo à discussão contínua sobre as relações entre filosofia, filosofia da religião, teologia e a(s) ciência(s) da religião em sentido estrito. Buscase, a partir de uma discussão contextual restrita ao ambiente brasileiro, tecer impressões gerais a partir de uma impostação propositalmente polêmica, que, porém, quer servir a considerações teóricas mais qualificadas que algumas atualmente prevalentes, e menos caracterizadas por estratégias defensivas, não raro até corporativas, pois motivadas pela urgência da sobrevivência política, institucional e acadêmica. No arcabouço dessa discussão maior, retoma-se o debate em torno da suposta "obsolescência" da fenomenologia da religião, caso típico e exemplar a requerer atenção filosófica-reflexiva; e em torno da pertença possível da filosofia da religião e da teologia à(s) ciência(s) da religião enquanto campo de estudos maleável - conquanto não tolerante a frouxidões quanto a teoria ou objeto -- e avesso a reducionismos metodológicos, sobretudo, mas não só, aqueles provenientes das ciências sociais. Em tudo isso o objetivo é endossar, mais uma vez, a complexidade do estudo da religião, evitando simplificações muitas vezes típicas de estudos empíricos e descritivos, cuja riqueza é muitas vezes apenas aparente, já que afinal o leigo pode sempre se perguntar: "Em todo esse caos, trata-se ainda de estudo da religião, este objeto específico prima facie reclamado por esta(s) ciência(s)?"
\end{abstract}

Palavras-chave: filosofia, filosofia da religião, teologia, ciência(s) da religião, teoria.

\footnotetext{
* PhD pela Lutheran School of Theology at Chicago. Professor Associado IV no Departamento de Filosofia da Universidade Federal de Juiz de Fora, onde atua na graduação, com ênfase na área de (História da) Filosofia Moderna. Estágios de pós-doutorado em filosofia da religião realizados pela Universität Hamburg e, em duas ocasiões, pela Martin-Luther Universität Halle-Wittenberg, onde foi também professor visitante. Coordenador do Núcleo de Pesquisas sobre Filosofia Clássica Alemã NUFCAL. E-mail dreher.teol.filos@gmail.com.
} 


\title{
The Contribution of Philosophy of Religion to the Sciences of Religion: General Impressions
}

\begin{abstract}
The following paper aims at providing one more contribution to the ongoing discussion about the relationships that obtain between philosophy, philosophy of religion, theology and the science(s) of religion in the strict sense. On the basis of a contextual discussion limited to the Brazilian scene, the effort is made to impart general impressions in an intentionally polemic style. In spite of this, the real goal is to lead to theoretical considerations which are qualitatively superior to some prevailing in current debates and less marked by defensive strategies frequently produced by the urge of political, institutional, and academic survival. Within the framework of this larger discussion, a point is made about the supposed "obsolescence" of phenomenology of religion, a typical and exemplary case still requiring attention of a philosophicalreflexive kind; and another about how philosophy of religion and theology may belong to the science(s) of religion understood as a field of studies which is both ductile - while not allowing for laxity as to theory and subject-matter - and averse to methodological reductionisms, especially - but not only - as displayed in the social sciences. Throughout the paper, the idea of the complexity of religion is endorsed and the attempt is made to avoid theoretical oversimplifications not rarely to be found in more empirical and descriptive research programs whose wealth is often only apparent, since at the end the layman can always ask: "In all this mess, is it still religion which is studied, namely this prima facie specific subject-matter claimed by this or these sciences?"
\end{abstract}

Keywords: philosophy, philosophy of religion, theology, science(s) of religion, theory.

\section{Introdução}

Por várias razões, o trabalho a seguir é, para seu autor, menos que uma publicação propriamente acadêmica; entende-se, antes, como o horizonte de possíveis contribuições futuras. Por ora, busca apenas atender ao convite, algo urgente, no sentido de apresentar os contornos gerais de uma compreensão de "filosofia da religião" naturalmente entre tantas outras possíveis. Tal convite poderia causar estranheza a não poucos, sobretudo quando se partisse do pressuposto de que, por ser este um contributo 
oriundo da "ciência(s) da religião", ele por definição excluiria a filosofia ao declarar-se de antemão o estudo da religião "científico" dentro de um registro estabelecido e corrente - mas nem por isso menos inquestionável e peculiar, aos olhos da filosofia! deste conceito.

Seja lá como for, dá-se efetiva e afortunadamente o caso de que há muito perdeu em evidência a noção da filosofia enquanto "ciência" no sentido razoável da palavra. Ficaram os filósofos, cada vez mais, com a impressão declarada de que tudo o que tem são os conceitos. E, no entanto, também diante desta aparente insuficiência haveria que acautelar-se o vulgo, ainda mais o cultor de qualquer ciência determinada - por mais estabelecida e autoconfiante que já seja. Embora não se trate de simples falsa modéstia, tal confissão não trai apenas melancolia. Pois é difícil para os filósofos - mesmo que não exibam as credenciais corporativas da mais pura estirpe - resistir à tentação de levantar perguntas e estabelecer sempre determinadas delimitações no conjunto das atividades cognitivas humanas; e de, como se tal pretensão não bastasse, ceder ainda, às vezes, ao charme que os convoca a discorrer de algum modo, mesmo indireto, sobre o todo, em vários sentidos do todo: o todo do conhecimento, do ser, etc. - com o que não se pára, necessariamente, por aí.

Mas estabelecer determinadas delimitações de nenhum modo é prerrogativa e costume apenas dos filósofos. Também as ciências particulares estabelecem limites e, consciente ou inadvertidamente, configuram suas próprias totalidades, tomando, não raro, sua parte pelo todo. Cabe sempre indagar, porém, sobre a justa motivação dos atos de delimitar-se e delimitar. Em que medida tal motivação é, por exemplo quando se trata de conceituações da religião, sequer idealmente, "pura", teórica, acadêmica? e em que medida refletiria antes, preponderantemente ao menos, interesses pessoais, pragmáticos, aqui e ali político-institucionais, militantes e até mesmo ideológicos? São estas indagações que não querem calar, e que cobram uma acuidade toda especial quando se fala de "filosofia da religião" tendo em mente a vizinhança, no geral

\footnotetext{
${ }^{1}$ Uma vez que este artigo não irá expressar aspirações nem sonhos, nem tampouco discutir aquelas que seriam as pré-condições teóricas para a constituição de uma disciplina passível de ser autenticamente chamada de "ciência da religião" (no singular), usarei doravante apenas o plural "ciências da religião", pois ele reflete melhor a realidade da situação atual desta disciplina no arcabouço institucional da pósgraduação brasileira - disciplina dentro da qual também se cultiva, atualmente, a filosofia da religião. Aquelas aspirações e sonhos, a desejabilidade de algo que talvez um dia pudesse ser gestado, como disciplina internamente coerente, fundada num princípio de relativa unidade de método e objeto, foi enunciada, e as pré-condições teóricas e epistemológicas para tanto foram também articuladas, rudimentarmente, é claro, num trabalho de nossa pena publicado em outro momento da discussão. Cf. Luís H. DREHER, Ciência(s) da Religião: Teoria e Pós-Graduação no Brasil. In: Faustino TEIXEIRA (Ed.). A(s) ciência(s) da religião: afirmação de uma área acadêmica. São Paulo: Paulinas, 2001, p. 15178. Naquele artigo, pelo menos o autor tinha clareza de estar falando de uma possível práxis de pesquisa que não se praticava ainda, e que hoje tampouco se pratica, mas que seria legítimo e útil praticar, dadas uma série de condições. Hoje, pergunta-se: poderá haver algum dia, com efeito, uma ciência da religião? Temo que, se nela houvesse um forte componente filosófico, por exemplo o fenomenológico em algum sentido deste termo quando aplicado ao estudo da religião, surgiriam queixas, em parte justas e cabíveis, de que não se trata de "ciência"; e que, se nela houvesse um componente social-científico dominante, tampouco se trataria de ciência da "religião", mas de algo que apenas toca numa dimensão arguivelmente muito superficial da mesma, e que poderia ser igualmente estudado por outras disciplinas, sem a necessidade de programas específicos para tal.
} 
benéfica, da teologia ${ }^{2}$ e da "área acadêmica" das ciências da religião ${ }^{3}$ que, entre tantos outros frutos significativos, deu vida a este admirável órgão de publicação periódica.

\section{A filosofia da religião na pós-graduação brasileira}

Como sói ocorrer noutras latitudes, é notório que também no Brasil a filosofia da religião se pratica, do ponto de vista institucional, em pelo menos duas áreas, ou ao menos subáreas, acadêmicas: filosofia e teologia - que, no caso brasileiro, acha-se, por várias e boas razões ainda, no mesmo barco e num tête-à-tête com as ciências da religião. No exterior, muito depende do contexto institucional ou da tradição filosófica, ou mesmo teológica, em questão. No Brasil, e no âmbito institucional da filosofia, já não há só pesquisadores isolados e dissertações isoladas ou "anômalas" orientadas em programas de pós-graduação, mas cresce a tendência de se constituírem programas de filosofia em que a filosofia da religião perfaz linha de pesquisa própria. ${ }^{4}$ Alça-se, assim, ao nível dos estudos pós-graduados, a presença histórica de décadas da disciplina em bem mais de um currículo universitário de filosofia em nível de graduação. ${ }^{5}$

Não por último, a própria ANPOF-Associação Nacional de Programas de PósGraduação em Filosofia viu, há poucos anos, com bons olhos a constituição de um "Grupo de Trabalho em Filosofia da Religião". Há concordância de que se trata de um objeto filosoficamente pertinente, passível de abordagem em mais de um registro ou tendência filosófica, e diante do qual recomenda-se a possível neutralidade teórica e, quando viável em meio às vicissitudes da vida - da qual nem mesmo os filósofos estão imunes - o trânsito não impedido por motivações político-ideológicas ou mesmo corporativas.

O critério único, como deve ser em todo discurso filosófico, seria, além da excelência e de certa remissão a um ou vários dos tratamentos típicos da religião na "tradição filosófica", a plausibilidade da argumentação e da fundamentação racional em ao menos um dos vários sentidos filosoficamente concorrentes desta expressão -, bem como a possibilidade de evidenciar as relações da disciplina filosófica em questão com outras, especialmente a gnosiologia, a axiologia e a ontologia (ou "metafísica"). Assim, também no estudo da religião, a abordagem tipicamente filosófica não consideraria qualquer pretensão científica como definitivamente desobrigada de uma fundamentação das asserções básicas sobre o objeto de pesquisa, em correlação ou

\footnotetext{
${ }^{2}$ Para uma discussão mais detalhada de "teologia" a partir do horizonte deste trabalho, cf. a seção 5 abaixo. Cabe adiantar que se trata, em todo o caso, de uma discussão do termo na tradição cristã, não só pelas dificuldades colocadas pela sua aplicabilidade a outras tradições religiosas, mas também pelas limitações do autor.

${ }^{3}$ Cf. TEIXEIRA (Ed.). A(s) ciência(s) da religião.

${ }^{4}$ Este é o caso do Mestrado em Filosofia da FAJE, de Belo Horizonte, em que a filosofia da religião, ao lado da ética, configura linha de pesquisa própria; e, segundo ouvimos - resta confirmar a informação do já estabelecido Mestrado em Filosofia da UnB, em que igualmente a filosofia da religião constitui, ou constituirá brevemente, linha de pesquisa autônoma.

${ }^{5}$ Ao menos na época em que estudei filosofia na UFRGS, existia a disciplina no currículo de graduação; o Dr. Álvaro Valls era, na época, se bem me lembro, responsável pela cadeira - além de ensinar filosofia na EST, em São Leopoldo. Na UFJF, eu mesmo já tive o prazer de lecionar esta disciplina inúmeras vezes. Haveria que fazer um levantamento nos currículos de graduação em filosofia para obter números exatos sobre o todo.
} 
não com outras asserções básicas sobre o conhecimento, os valores, o mundo, o homem, seu ambiente etc.

Quando se volta a atenção para o dado histórico, também a filosofia, assim como a teologia naqueles poucos casos em que não era nem tutelada por um poder alheio nem totalmente indiferente à primeira, teve um papel importante na constituição da área de estudos denominada, entre nós, de "ciências da religião". Como se sabe, porém, não é hábito da filosofia ceder à tentação de transformar qualquer constatação em nível fático, positivo ou histórico, em um dogma inabalável. Não há nenhum compromisso ineludível no flerte factual, mais multifacetado e interessante do que se supõe, ${ }^{6}$ das ciências da religião com a filosofia mediante o objeto que lhes é comum. Noutras palavras, é teoricamente possível que o papel da filosofia e de certa teologia na constituição histórica das ciências da religião venha a tornar-se cada vez mais "histórico", no sentido de uma contingência, algo em processo de ser superado por práticas intelectuais mais científicas e mais sóbrias, e que dão mais conta da integralidade do objeto pesquisado.

Seja qual for o futuro - aos profetas cabe a resposta -, tampouco há uma mútua exclusão, de princípio, entre filosofia e ciências da religião. Aqui impõe-se um paralelismo significativo com o fato de que nem toda filosofia exclui, já por princípio, a religião. Tal atitude matizada, sempre ainda propriamente filosófica, observa-se quer naqueles casos em que a religião é acolhida, de algum modo, em sua própria definição de si, após o que sua possível racionalidade enquanto objeto ou forma de vida é investigada; quer naqueles casos em que a definição da religião é construída ou reconstruída ("traduzida") pela filosofia dentro de um marco sistemático mais geral que se abre, ao lado de outros possíveis, aos testes da coerência, da correspondência ou da validade. Como se vê, em ambos os exemplos a filosofia repele a facticidade sedutora do senso comum e daquela parte da prática científica que confunde metodologia com explicação total, ou seja, a parte com o todo. Ela não pretende já saber de antemão o que é a religião, mas precisa ou captar e justificar filosoficamente o conceito-de-si da religião ou propor o seu próprio conceito como mais compatível com a "realidade" filosoficamente articulada. Em qualquer um dos casos, a filosofia não aceita, assim como não aceitaria nenhum aduaneiro experiente, o valor nominal ou declarado da "mercadoria" que é a definição da religião já sempre embutida, dentro de nexos explicativos que por vezes não podem ou não querem justificar-se num nível mais geral, quer na própria metodologia científica, quer na prática científica efetiva.

Por outro lado - e talvez fazendo jus, numa boa causa, porém, ao estereótipo segundo o qual habitaria em torre de marfim -, a filosofia dispõe, em princípio ao menos, de maior imunidade à tão comum tendência de endossar carências de tipo prático, pragmático ou político alçando-as, por algum hocus-pocus pretensamente imperceptível, à condição de obrigações de tipo epistêmico ou metodológico. A filosofia não pretende mudar o mundo antes de entendê-lo propriamente, e este seu

\footnotetext{
${ }^{6}$ Este "flerte" se dá, num exemplo, pela aproximação comum das ciências da religião e da filosofia à esfera da arte, como no caso da literatura enquanto uma possível forma de expressão e articulação do elemento religioso. A arte, que por via de regra relaciona a experiência do estético com aquela da verdade, permanece inclusive, aqui e ali, como um caminho ou modelo de aproximação da religião em várias disciplinas, às vezes como alternativa declarada à tendência científica nos estudos da religião.
} 
sacerdócio, admitidamente peculiar, é o antídoto à uma só vez mais impotente e mais eficaz contra os vários intentos de aboli-la. Tal sacerdócio, baseado numa hierarquia que ou bem é intrinsecamente válida ou então inoperante, veda à filosofia aceitar, ingenuamente e sem exame, qualquer narrativa sobre a pretensa ultrapassagem epocal dos seus próprios direitos de conceituar e investigar a religião e as religiões. Tais direitos permanecem, mesmo depois de interpretada(s) esta(s), ou até, em casos admitidamente mais raros, pretensamente dissecada(s) pela interpretação, a partir dos registros de cunho histórico, psicológico e social-científico - entendidos aqui, obviamente, segundo as conotações mais extremas e autossuficientes destes termos.

Uma das razões da grande utilidade da filosofia, e sobretudo da filosofia da religião, para as ciências da religião, acha-se na impossibilidade de safar-se de e eludir definições e conceitos - operacionais ou definitivos, estes últimos no sentido de "explicativos" e "normativos" - de "religião". Tais conceitos de "religião" (no singular!), embora atacados com frequência e necessariamente criticáveis e revisáveis, são pressupostos em qualquer forma de estudo das religiões empíricas, em qualquer uma de suas complexas facetas. (Aliás, nenhuma ciência, enquanto ciência, pode reivindicar que seu objeto é pura positividade, enquanto positividade; toda positividade é sempre também para a consciência.)

Duas últimas observações. Primeira: na raiz de várias confusões encontradiças entre estudiosos iniciantes da religião, mas também entre um e outro filósofo da mais elevada competência e sutileza dialética, ávidos às vezes por dissociar seus próprios heróis (por vezes até mais: santos!) de qualquer relação com termos estigmatizados como "dogma", "teologia" e quejandos ${ }^{7}$, está o proton pseudos que mistura, com pouca ou nenhuma qualificação, conceitos que não possuem a mesma extensão, e que soem inclusive estar, por vezes, em conflito, a saber "igreja" - ademais entendida redutivamente, como uma estrutura de poder apenas - e "religião". ${ }^{8}$ Por vezes tal erro é,

\footnotetext{
${ }^{7}$ Em princípio, mesmo a teologia, quando dogmática em sentido não-pejorativo - o termo "dogmático" tornou-se pejorativo só a partir da modernidade, a partir de autores que às vezes dogmatizavam com fervor comparável aos dos teólogos - poderia entreter uma relação livre, "interpretativa" (=hermenêutica) com a tradição da qual provém aquelas que são as suas verdades. Daí a designação mais utilizada, atualmente, de teologia sistemática, que porém é mais vital, e não só nominal, dentro daquelas formas de protestantismo que buscaram uma relação positiva com o que há de inelidível na herança da modernidade.

${ }^{8}$ Tal confusão conceitual é detectada por um dos entrevistados sobre a trajetória (apenas inicial ou ainda vigente?) das ciências da religião no Brasil. Ele identifica sua radicação em habituais intelectuais originalmente "franceses", que, possivelmente através de mediações da teoria sociológica e revolucionária, tornaram-se uma espécie de patrimônio da cultura acadêmica brasileira: "Penso também que o fato de muitos brasileiros terem saído da influência francesa também é importante. Porque na França, depois da Revolução, houve um corte mesmo: Igreja pra lá e Estado pra cá, a secularização, e isso marcou muito o pensamento francês. Agora, quando a USP começou foi interessante, vieram cientistas tipicamente franceses interessados em religião. Acho que isso ajudou. Agora, no campo da Filosofia, não: lá, os franceses até hoje são muito hostis às religiões. $\mathrm{Na}$ Alemanha não, lá há vários pensadores importantes - alguns nós estudamos aqui - que não têm essa ojeriza em relação à religião." (Cf. Ângela Cristina Borges MARQUES, Marcelo ROCHA, Memórias da fase inicial da Ciência da Religião no Brasil - Entrevistas com Edênio Valle, José J. Queiroz e Antonio Gouvêa Mendonça, Rever: Revista de Estudos da Religião, n. 1, 2007, p. 203. Trata-se de entrevista concedida, neste ponto do texto, pelo prof. Dr. Edênio Valle.) É apenas curioso o fato de que estes pensadores alemães importantes, muitos deles ligados à tradição filosófica, nem sempre recebam uma avaliação mais isenta justamente de parte de alguns setores das ciências sociais da religião aparentemente comprometidos com estratos mais hostis da
} 
na melhor das hipóteses, também um auto-engano; na pior, torna-se instrumento crucial de interesses que não são estritamente científicos.

Segunda: se bem que a filosofia, quando bem praticada, se interesse e aprenda de todas as pesquisas empíricas - sem deixar-se fascinar por qualquer possível aura de "pura positividade"! -, não são elas a sua própria pesquisa. Para a filosofia, são apenas informação e descrição, às vezes interessante, às vezes relevante, às vezes nem uma, nem outra. Neste sentido, a filosofia da religião tem excelentes razões para continuar a reclamar, para si, a distinção, originariamente filosófica, entre o ideal e o real na religião. $\mathrm{O}$ fato de que, por exemplo, uma disciplina como a antropologia tenha chegado a adquirir legitimidade epistêmica própria em alguma medida a partir de fatores históricos, como o crescente pessimismo em relação à civilização ocidental, ${ }^{9}$ do qual é correlato a pungência da mensagem ética de suas descrições de como amiúde factualmente se julgou, no passado recente, outras religiões reais com a régua da própria religião ideal e idealizada, não é prova suficiente para dispensar a necessidade de conceitos operacionais - mas também tendencialmente definitivos, explicativos! - de

modernidade não só diante de certas formações tradicionais (tidas como "hegemônicas", “ideológicas”) da religião positiva, mas também da religião entendida como algum tipo de experiência humana dotada de validade própria. Só a partir deste pano de fundo se pode entender, p. ex., o juízo global e pouco matizado acerca de F. D. E. Schleiermacher por USARSKI, Frank. Constituintes da ciência da religião: cinco ensaios em prol de uma disciplina autônoma. São Paulo: Paulinas, 2006, p. 20; 42. Pergunta-se o que poderia significar, p. ex., o rótulo "abordagem unilateralmente universalista" - haveria quem sabe, a possibilidade de direito, uma abordagem "parcialmente" universalista? qual seria ela? -; e como seria então fundamentada (filosoficamente) a perspectiva (iluminista) oposta, que privilegia e se limita às "funções externas das religiões concretas". Ademais, atribui-se a meu ver erroneamente a Schleiermacher - erro que em minha opinião se estende à avaliação de R. Otto - a formulação do numinoso como uma "entidade ontológica absoluta". Isso não faz sentido para quem leu, ao menos algumas linhas, da Dialética de Schleiermacher; para quem consegue discernir sua oposição ao idealismo absoluto de Hegel, e ademais consegue identificar a vinculação de Schleiermacher e Otto à tradição kantiana, para ambos fundamental. Mas provavelmente o Absoluto, pensado como postulado a partir da razão prática ou pressentido na intuição ou sentimento religioso, já seja ontologia demais para quem pensasse que a empiria é uma grandeza autoexplicativa, ela mesma dotada de certa "absolutidade". Embora seja preciso reconhecer o imenso valor da dedicação e atividade do Prof. Usarski, como um dos poucos que leva a sério e desenvolve com reconhecida profundidade a discussão teórica em torno da possível unidade teórica de uma área disciplinar já existente de facto, é de se perguntar se a ciência da religião de corte empirista que ele parece querer representar - suas referências a F. Bacon não devem ser nem inocentes, nem gratuitas (103ss) - não implica um conceito mais definitivo de religião do que se poderia prima facie pensar.

9 Nesse sentido, é curioso, para não dizer paradoxal, ao menos numa certa leitura possível, que tal pessimismo quanto ao Ocidente, suas tradições e instituições principais seja às vezes acoplado acriticamente a algum tipo de "humanismo" que mostra preferência criptoreligiosa ou criptocristã pelo que é estranho e minoritário, pelo que é marginal ao mainstream das tradições religiosas, éticas e políticas. A defesa deste humanismo seria ou é de fato entendida como a indispensável dimensão política das ciências humanas e sociais; ela visa, talvez, dirimir a ansiedade sobre a relevância última das práticas científicas em questão. O problema é que as recomendações de tolerância, mais do que serem fundamentadas em sua evidência numa ética teológica ou filosófica de fundo e nas exigidas práticas correspondentes, são embutidas no método científico como um verniz, com o que se teria a impressão de que as boas intenções das ciências seriam suficientes não só para constituir e justificar o saber socialmente, mas sobretudo para defendê-lo institucionalmente diante de saberes tradicionais, tidos como ideológicos em algum sentido da palavra. 
religião. Quem nisso vê algum tipo de prova comete a falácia que os antigos já conheciam, grosso modo, como a "passagem para um outro gênero de assunto".

Pelo contrário! Os exemplos da desmedida humana também nesta questão, mas não só nela, e que podem se repetir e de fato já se repetem, agora, visivelmente mesmo fora da esfera do cristianismo e mesmo entre religiões minoritárias, prova antes que persiste, em algum sentido, um "ideal" do que seja a religião. Para se começar a fazer filosofia da religião é preciso reconhecer isso e precisar, com os mesmos padrões éticos de senso comum de que podem e devem ser expressão todas as disciplinas intelectuais, este ideal. Ao não se começar a fazer isso, pode-se fazer algo mais "científico", mas que não estará jamais imune de seus próprios perigos, nem da necessidade de justificar-se diante de mais elevados tribunais.

\section{Um exemplo de aplicação da filosofia no estudo da religião: o "vivo" e o "morto" na fenomenologia da religião}

Uma forma concreta de incidência da filosofia da religião nos debates sobre os estudos "científicos" da religião ocorre sempre que se busca avaliar o estatuto da fenomenologia, em suas várias orientações teóricas e aplicações, dentro destes estudos. Parodiando o título de um livro de B. Croce, este modesto trabalho parte do pressuposto que pode ainda haver algo de "vivo" em tal abordagem, e busca questionar vereditos ou oráculos em contrário. ${ }^{10}$

Naturalmente - e como não pode deixar de ser em se tratando de um trabalho na perspectiva de uma filosofia da religião modesta -, poder-se-ia conceder que, no final das contas, talvez o elemento "vivo" na fenomenologia continue a interessar somente aos filósofos. Mas isso é matéria incerta, e não deixa de trair a postura oracular, recém declinada por nós, que desde antanho é estranha ao quefazer filosófico. Mesmo assim, e correndo riscos: seria de aventar que a possível veracidade deste prognóstico tem a ver com o fato de que a fenomenologia da religião, além de ser uma candidata permanente e quiçá incômoda - ao posto cobiçado de princípio sistematizador de uma novamente polêmica, passada e quiçá futura ciência da religião - pois hoje de facto institucionalmente inexistente -, configura também, e antes de mais nada, ao menos em algumas de suas expressões, um tipo característico de filosofia da religião. ${ }^{11}$ (E, como é sabido, em filosofia nunca nada está simplesmente morto; ela tem uma relação mais distanciada com os gostos ou decretos dos tempos. Por isso, talvez, ter-se-á podido chegar ao veredito, ao menos parcialmente crível, segundo o qual a filosofia ocidental não seria senão uma grande série de notas de rodapé ao platonismo.)

Mas retornando ao ponto, a saber, aos debates sobre os estudos "científicos" da religião. É possível identificar uma dificuldade preliminar, que deles poderia surgir

\footnotetext{
${ }^{10}$ Cf. tb. n. 25 abaixo.

11 SCHAEFFLER, Richard. Filosofia da Religião. Trad. Artur Morão. Lisboa: Edições 70, 1992, p. 75102. Discordam disso Klaus-M. KODALLE, Michael KÜHNLEIN, Religionsphilosophie. In: PIEPER, Annemarie (Ed.). Philosophische Disziplinen: Ein Handbuch. Leipzig: Reclam, 1998, p. 344, n*, que preferem incorporar a "teoria da religião que opera fenomenologicamente a partir da manifestação empírica das religiões" à "ciência da religião" (!). O problema parece ser que talvez tenha havido, mesmo entre os fenomenólogos da religião, ao menos os mais clássicos, discordância quanto ao papel do elemento empírico da religião que é tão posto em relevo pelos autores.
} 
futuramente, a saber: a mistura implícita, mas sempre impura, de validade e poder. Tal mistura é sabidamente difícil de evitar, talvez em alguma medida inevitável até o que, porém, não implica, automaticamente, sua legitimidade. Pode-se, por exemplo, fazer um esforço imaginativo e levantar a hipótese de que ainda está por ser publicado mais de um escrito autodeclaradamente acadêmico - e mesmo aqui haverá diferenças quanto ao grau de satisfação, sempre nalguma medida existente, deste critério tomado isoladamente - com a intenção, inconsciente, semiconsciente ou até consciente, de "aparelhar" ou "ocupar espaço" diante de forças percebidas, paranoicamente ou não, como concorrentes numa disputa de influência e de poder.

Esses casos, se ocorressem, felizmente seriam poucos - aqui o autor ousa sim vaticinar, a partir de experiências passadas e presentes, que inspiram grande confiança na qualidade geral e maturidade, já incontestável, de nossa área acadêmica. Mas o perigo latente em casos hipotéticos como estes seria a simbiose da argumentação de caráter propriamente epistemológico e metodológico, muitas vezes válida e merecedora de consideração no todo ou pontualmente, com modalidades de discurso que traduziriam interesses acadêmicos no sentido já bem mais raso, corporativo dos termos "acadêmico" ou "academia". (Espera-se que não sejam, estas exceções, se um dia efetivamente vierem a se constituir, as parceiras de diálogo de possíveis contribuições mais demoradas, de nossa pena, ao assunto.)

Um argumento corrente, que às vezes aparece relacionado com este tipo impuro de abordagem, é o de que a fenomenologia como um todo, e não só em alguns aspectos naturalmente datados - e tudo que é histórico é ou será datado, inclusive a ciência hoje praticada por aqueles que também somos, bem ou mal, "cientistas da religião"! -, estaria ultrapassada ${ }^{12}$; de que toda fenomenologia seria não só uma teologia disfarçada, mas também incuravelmente eurocêntrica, em todo o caso dogmática ou politicamente incorreta; ou de que representaria uma forma de filosofia superada pelos mundos claros das ciências naturais e sociais, pois que ainda incuravelmente "essencialista" e "metafísica" - como se só na filosofia (e na teologia) houvesse "metafísica" e cosmovisão, disfarçada ou nem tanto. (Aliás: em filosofia geralmente uma das coisas que está em jogo é justamente o conceito assaz complexo de "metafísica", que porém fica subitamente fácil de entender em contextos marcados pela retórica, aqui e ali pela polêmica, dos não-especialistas. ${ }^{13}$ )

Infelizmente, aqui não é possível entrar em detalhe numa discussão quer sobre a consistência destes argumentos, quer sobre os pressupostos em que se baseiam. ${ }^{14}$ Abstraindo-se por um momento, porém, do valor argumentativo destas que, aqui e ali, parecem estratégias de rotulação imprecisas e mesmo retóricas, fica evidente o inegável

\footnotetext{
12 Este argumento implica por vezes um apelo implícito, mas surpreendente, à normatividade do Zeitgeist atual, num contraste curioso com uma historicização completa e impiedosa do contexto gerador da clássica fenomenologia da religião. Talvez implique, também, a tese de que a formulação mais unitária existente ou desejável - da(s) ciência(s) da religião, sobretudo em sua base metodológico-sistemática, teria já alcançado, definitivamente, algum estatuto de "ciência normal".

${ }^{13}$ Sobre "metafísica", cp. n. 43 abaixo.

14 Para obter subsídios iniciais sobre estes argumentos e posicionamentos algo diferenciados, remete-se o leitor a USARSKI, Constituintes da ciência da religião, esp. 29-54; e BRANDT, Hermann. As ciências da religião numa perspectiva intercultural: a percepção oposta da fenomenologia da religião no Brasil e na Alemanha. Estudos Teológicos, v. 46, n.1, São Leopoldo, 2006, p. 122-51.
} 
interesse político e corporativo, nelas contido, de dissociar os estudos da religião de qualquer contaminação disciplinar, ou, pior ainda, departamental-institucional, pela filosofia e pela teologia, como se por si só isso fosse já a garantia de cientificidade ou o que já preocuparia mais um filósofo, "puro" ou não! - de excelência ou solidez argumentativa. Todos sabem que, institucionalmente, também a área de estudos da religião é campo minado por lutas ideológicas e políticas concretas que têm seu próprio valor e sentido, mas que, para o bem de uma comunicação e de um processo de reconhecimento mais genuínos, deveriam ser distinguidas quanto possível de debates epistemológicos e filosóficos de fundo.

Exemplos: tal área é marcada por colaboração genuína, mas também por rivalidades entre culturas acadêmicas às vezes concorrentes, por tradições epistêmicas e áreas de conhecimento já há tempo estabelecidas, especialmente em universidades públicas, como aquela na qual atuo; ou por antagonismos como os que ficam latentes ou surgem aqui e ali, especialmente em instituições confessionais de ensino e pesquisa, sobretudo nas católicas e neste momento - mas não só nelas -, entre "clero" e "leigos", "progressistas" e "conservadores", ou entre "ortodoxia" e o que é visto já não como um simples estudo idealmente autônomo da religião, mas como "teologia", ou "a-teologia", concorrente. (Existe, parece, uma diferença óbvia e importante entre, por um lado, estudar com isenção a religião e as religiões, servindo-se de qualquer método que se comprove sem esquecer seu alcance e seus limites; e, por outro, simultaneamente fazer desse estudo um instrumento rasteiramente cosmovisivo, ele mesmo impérvio à crítica, de simples apologia ou crítica, quer parcial ou total, da "igreja" ou da "religião", entendida, por hipótese, seja como dogma ou hierarquia, seja como ideologia ou idolatria no todo e nos detalhes.)

A verdade é que, embora o gesto de dissociar os estudos da religião de qualquer contaminação disciplinar seja já de um ponto de vista histórico taticamente imprudente, por terem a filosofia e a teologia dado, e continuarem a dar, tão importante contribuição aos estudos da religião e sua institucionalização no país, o alvo não deixa de ser bem visado do ponto de vista pragmático. Pois na questão do estudo da religião houve e continua a haver, proporcionalmente, ainda significativa confluência entre teologia e algumas abordagens importantes da filosofia, senão necessariamente nas soluções, ao menos no estilo de colocar questões e no rol de alguns dos problemas relevantes, por exemplo problemas pertinentes à ética e à metafísica.

E embora - só para pôr um exemplo - filósofos naturalistas tendam no geral a interessar-se menos por religião, permanece o fato de que, quando se interessam, têm que confrontar-se com questões de estrutura mais ou menos semelhante. Outrossim, geralmente sabem que as convicções básicas que conformam seu posicionamento sobre a religião podem no mínimo ser confrontadas por convicções básicas de outra natureza, com as quais devem necessariamente dialogar e, no limite, recusar para si, sem, contudo, dissimular sua decisão com predicados de universalidade ao modo da cientificidade, ou seja, aquele que toma sua parte pelo todo, mas que deve sempre fazêlo dentro de um marco de redução apenas metodológica. (Isso, aliás, diferencia a filosofia, e por extensão a filosofia da religião, das ciências: elas são, necessária e admitidamente, ato vital e existencial, Lebensvollzug, na sua articulação de universalidade.) 
Ainda quanto à confluência parcial mencionada, é possível e necessário dizer mais. Embora muitos fenomenólogos da religião fossem também teólogos, por via de regra protestantes, e nem sempre filósofos "puros" no sentido corporativo dos portadores de titulação, não por último em razão do caldo de cultura em que se moviam, não há como negar que as raízes mais profundas da fenomenologia da religião não são diretamente teológicas. Também nesse caso, há que considerar seus argumentos originais a partir da sua contextualidade sistemática e filosófica, e não despedir os primeiros fenomenólogos por terem sido batizados na confissão evangélico-protestante e terem crescido e pensado a partir de certas variáveis que psicologicamente sempre se pode desvendar, como quaisquer outras. ${ }^{15}$

Antes, o que se torna indispensável simplesmente ressaltar, neste breve espaço, é que tais raízes filosóficas não excluem, por princípio, o possível valor e pertinência obviamente não direta e nem em estado bruto - dos dados sobre os quais opera a teologia, tais como a "revelação" (que, afinal, se é que se revela, revela-se para uma subjetividade finita) ou, numa variação mais modesta, a "fé", dado psíquico e intencional inegável da consciência. Com efeito, gostaria de levantar a suspeita de que atacar a fenomenologia da religião, com qualquer grau de virulência, significa, ao menos tendencialmente, entrar numa disputa que não é só da "ciência" com a "teologia", pensadas seja como chavões ou já nas inúmeras concreções de sua multifária complexidade, mas que pode prontamente tornar-se fundamental, isto é, "filosófica".

Bem, e para ser brevíssimo: onde estão as raízes mencionadas da fenomenologia da religião? Estão, sim, na filosofia; e não só na elaboração própria e algo idiossincrática - sobretudo para espectadores que por vezes casam com toda a facilidade, eles mesmos, relativismos e absolutismos - do pensamento "rigoroso" de E. Husserl e de vários de seus criativos seguidores. Aquelas raízes estão também na filosofia crítica de I. Kant, a qual, passando por ajustes e aditamentos em vários autores do século XIX, acabou por configurar a esfera daquilo que, apresentando-se em várias manifestações vivenciais, ideativas e "empíricas", é estudado por teólogos, historiadores, cientistas sociais, etc., mas que parece, até melhor e bem mais definitivo insight, reivindicar, para si, uma esfera própria e independente de validade (Geltung, Gültigkeit, Validity) no âmbito da experiência humana total; ${ }^{16}$ e não, como prefeririam

\footnotetext{
15 Até melhor e mais justa leitura, é o que parece, ao menos em parte, ocorrer em USARSKI, Constituintes da ciência da religião, p. 37.

16 Para o sentido de "validade" a partir de I. Kant, amparado tanto no texto da Crítica da razão pura [CRP] como no da Crítica do juízo [CJ], cf. CAYGILL, Howard. Dicionário Kant. Trad. Álvaro Cabral. Rio de Janeiro: Jorge Zahar, 2000 [1995], p. 315: “(...) em CJ, ele [Kant, LHD] discordou de sua própria posição e admitiu um sensus communis ou sentido comum que poderia levar a juízos universalmente compartilhados e necessariamente válidos sem uma 'unidade do objeto'. Com efeito, ele atribuiu 'validade exemplar' a juízos estéticos de gosto na base do sentido comum como 'norma ideal', ou uma idéia que é 'subjetivamente universal' mas 'necessária a todos e a cada um' (CJ § 22). Entretanto, a idéia de um sensus communis não pode ser usada numa base constitutiva, mas tão-somente regulativa; isso, porém, não precisa ser necessariamente prejudicial à sua validade. Esse fato é evidenciado em CRP, onde Kant admite na classe dos juízos objetivamente válidos aqueles que são governados por princípios constitutivos e regulativos. A validade objetiva é conferida não só àqueles juízos que possuem 'validade imanente' em virtude de obedecerem às condições formais de uma experiência possível (CRP A 638/B 666), mas também àquelas idéias regulativas assintóticas que possuem "validade objetiva porém indeterminada' (A 663/B 691).” Como se vê, não é de um amador em filosofia que surgem ponderações
} 
ocasionais candidatos a detratores da filosofia crítica e da fenomenologia, num além objetificado, "essencialista", ${ }^{17}$ "metafísico" segundo o conceito de um positivismo residual, mas ainda curiosamente imperante, como "saber natural", entre metodólogos bastante sofisticados.

Aliás: muito embora haja muitas discordâncias sobre o conceito de essência em filosofia e na fenomenologia da religião - conceito ao qual deveria remeter-se qualquer discurso crível, mesmo de viés crítico, sobre o "essencialismo" -, é instrutivo dar alguma indicação sobre o tema a partir de Husserl, que foi, sabidamente, um dos vários grandes filósofos que ousou falar do tema. É impossível, porém, entrar em maiores detalhes neste modesto escrito. O que se pode fazer é apenas oferecer duas citações extensas que, se bem lidas, darão subsídios para começar a compreender, ao menos na fenomenologia derivada de e relacionada com Husserl, ${ }^{18}$ o conceito de "essência" e sua delimitação diante de filosofias concorrentes. São elas, da pena de um comentador dos mais competentes:

Desde o início de sua carreira filosófica, Husserl opôs-se ao que ele chamava o "dualismo"
de Kant, o "construcionismo" de Hegel e o "naturalismo" ou "psicologismo" dos
positivistas. Ele concorda com eles ao afirmar que somente fenômenos são dados, mas
defenderá a tese de que neles é dada a própria essência daquilo que é. Aqui não se tem um
interesse na realidade como existente, já que a existência é, na melhor das hipóteses,
contingente, e como tal não pode acrescentar nada à realidade que viesse a ser objeto de um
conhecimento científico. Uma vez que se descreveu os fenômenos, descreveu-se tudo que
pode ser descrito, mas nos próprios elementos constantes daquela descrição revela-se a
essência do que é descrito. Uma tal descrição não pode dizer nada relativamente à existência

que depois influenciaram uma série de estudiosos, possibilitando-lhes falar, p. ex., até mesmo de um "apriori religioso", como no caso do teólogo e filósofo da religião sueco A. Nygren. Considere-se a seguinte citação deste autor, que desenvolve Kant naquele que, em sua opinião - e com sólida argumentação -, é o espírito de Kant: "Thus, religion has first to be considered from the vantage point of its own center, and not from its connections to other forms of experience. This is the specific task of philosophy, namely, to give appropriate consideration to the matter of the specific religious apriori. The interest of critical philosophy of religion, in this regard, lies in direct opposition to the well-known words of Goethe: "whoever possesses science and art also possesses religion. " Not true. While it may be admitted that religion is ubiquitous in human consciousness, religion cannot be replaced or substituted for by the other functions of consciousness. Philosophy of religion, which is oriented toward the validity and uniqueness of religion, has much greater interest in examining religion on its own grounds than in collecting whatever scraps might be scattered on the grounds of its neighbors. ... For the critical philosophy of religion, the question about the truth of religion is identical to the question of the character of its necessity and validity." (Cf. NYGREN, Anders. Religious Apriori. (Linköping Studies in Religion and Religious Education, n. 2.). Trad. Kjell O. Lejon. Linköping: Linköping University Electronic Press, 2000 [1921], p. 49-50.

17 Ao essencialismo se contrapõe o "contextualismo" (cf. uma breve descrição e avaliação crítica em CRUZ, Eduardo R. A persistência dos deuses: religião, cultura e natureza. São Paulo: UNESP, 2004, especialmente cap. 5.) Sua justificação mais que puramente metodológica parece estar ligada a concepções que desde antanho se costuma, filosoficamente, classificar como "nominalistas". No nível da fundamentação estritamente filosófica, o nominalismo teve uma forte retomada no século XX, já não a partir de uma teoria tendencialmente empirista da realidade, mas a partir de posições que alçaram a linguagem a uma posição de centralidade no fazer filosófico, destacando-se, sempre, a maior ou menor especificidade e incomensurabilidade de sistemas lingüísticos, jogos de linguagem etc.

${ }^{18}$ Da qual destoa, admitidamente mais de um fenomenólogo da religião, sem que com isso já se torne um "metafísico" no sentido polêmico do termo, herdado obviamente, entre outros, de F. Bacon e D. Hume. 
do que é descrito, mas a "intuição" fenomenológica na qual termina a descrição nos diz $o$ que seu objeto é necessariamente. Saber isso é possuir um conhecimento "essencial", e, portanto, "científico", do ser. 19

\section{E, adiante:}

... geralmente se considera o filósofo escolástico como um realista, ao passo que Husserl, por sua própria admissão, é um idealista. $\mathrm{O}$ escolástico pertence àquela ampla corrente que podemos chamar de aristotelismo, e pertence-lhe, por assim dizer, por inclinação. Husserl, por outro lado, também por inclinação, pertence àquela outra ampla corrente que podemos chamar de platonismo. ... De fato, há um sentido em que Husserl, como diz Dilthey, é um platônico rematado. Para ele, a essência é verdadeiramente uma essência eterna, precisamente porque é completamente independente da existência em qualquer sentido desta palavra muito mal-usada. Uma coisa, um evento, uma ação ou um pensamento é o que é, quer ele exista ou não. É possível conhecer o que algo é sem qualquer referência a se ele é ou não. Portanto, não se trata, de modo algum, de "abstrair" a essência da realidade empírica. A essência, por conseguinte, não é uma capacidade para a existência; ela é simplesmente a realidade que, se existe, não é diferente da mesma realidade não existindo. Com Kant, Husserl não vê absolutamente nenhuma diferença inteligível entre cem táleres reais e cem possíveis. Para o escolástico, a essência é a fonte da inteligibilidade em toda e qualquer coisa; para Husserl, é a própria inteligibilidade: a essência e a inteligibilidade são conversíveis, e a existência como um impedimento para a inteligibilidade deve ser filtrada antes que qualquer investigação filosófica possa propriamente começar. Dizer que se captou a essência de algo é dizer que se captou seu sentido. Assim, para Husserl, essência e "sentido" são estritamente idênticos. O verdadeiro conhecimento da realidade é, pois, o conhecimento do sentido, da significação das coisas. Mas o sentido das coisas, sua significação, não pode ser encontrada em um mundo contingente de coisas existentes independentemente da consciência; há que ser encontrada precisamente na consciência, onde, admitidamente, concentra-se a significação. ${ }^{20}$

\section{Filosofia da religião: "ciência da religião" em sentido amplo}

O caso da fenomenologia (e da fenomenologia da religião) foi trazido à baila tão precocemente neste trabalho porque passou a representar, como é sabido, um verdadeiro pomo de discórdia em discussões de área no exterior, mas ultimamente também no Brasil. Ao mesmo tempo, tal caso talvez seja instrutivo; ele pode ser, no futuro, a prova de fogo para se obter algum discernimento sobre questões importantes, mesmo que "morra" completamente a fenomenologia.

Ele parece ser bastante apto, no momento, para encaminhar à questão que nos interessa mais de perto: qual o papel da filosofia da religião nos estudos pós-graduados brasileiros, sobretudo na subárea acadêmica de teologia e ciências da religião? Abstraindo de todas as disputas por sobrevivência, também as de tipo corporativo, político e ideológico, se é que isso será algum dia possível, e levantando a pergunta pela validade de uma pretensão: a filosofia da religião terá algo a contribuir para o futuro desta área? Será a área de ciências da religião verdadeiramente multidisciplinar em toda a extensão requerida pelo objeto, de direito e oxalá de fato? Será possível, ademais,

${ }^{19}$ LAUER, Quentin. Phenomenology: Its Genesis and Prospect. New York: Harper \& Row, 1965 [1958], p. 3-4. [As traduções destas citações ao português são do autor deste trabalho.]

${ }^{20}$ Ibid., p. 21. 
suportar a precariedade epistêmica - admitidamente sedutora porque "mal-comportada" - desta formulação plural sem incorrer no risco, que aqui e ali se insinua, de fazer disso uma desculpa inconsciente para a mediocridade e a incomunicação de especialistas? E, se não quisermos nada disso: quem ou que saber metodológico irá "sistematizar" a passada e futura "ciência da religião", não enquanto desiderato ou prática pontual de uns poucos, mas como disciplina e saber institucionalizados como tais, já num sentido mais forte?

Quanto a isso, deve-se dizer, em primeiro lugar, que embora a tese da área multidisciplinar tenha tudo para estabelecer-se como a grande vencedora no futuro, continua a ter razão a posição de que seria diletantismo falar de ciências da religião num sentido mais sério, ou seja, não só buscando delimitar, em nível político-pragmáticoinstitucional, uma área relevante de pesquisa - pois dúvidas sobre tal relevância já são bem raras - sem assumir claramente o compromisso de discutir os conceitos de ciência e de religião. ${ }^{21}$ Há um sentido muito óbvio no qual, dependendo do que seja entendido por ciência, a filosofia não é, e alegra-se mesmo por não ser, ciência. De modo algum é percebido como uma deficiência, na autoconsciência de vários representantes deste saber, o fato de não ser ele adequado, por exemplo, ao modelo que, bem grosso modo, podemos caracterizar como o modelo baconiano e positivista de ciência, que virou uma espécie de habitus irrefletido de mais de um estudioso da religião.

Um fator fundamental que faz da filosofia e mesmo de qualquer teologia livre (ou, caso se queira, "pública") disciplinas diferenciadas no estudo da religião é sua consciência do problema hermenêutico. Ou seja - e novamente bem grosso modo -, a consideração de que a objetividade no estudo da religião, embora desejável e idealmente possível, só pode ser alcançada pela inclusão do problemático, e mesmo intrigante componente, que é a subjetividade humana. É justamente a consideração do caráter eminentemente interpretativo deste ser que é o ser humano que torna problemática qualquer consideração objetificante e redutiva dos fenômenos humanos, entre os quais, para nós, destaca-se de maneira proeminente a religião.

Para alguns cientistas da religião isso poderia até parecer um gesto interesseiro dos "complicadores" hermenêuticos, ${ }^{22}$ diante da qual se prescreveria, como corretivo, a exigência da neutralidade. A defesa deste gesto eu deixaria, naturalmente com a prévia aquiescência deles, aos meus colegas, um pouco mais "hermeneutas" que eu, da UFJF e de outras partes. De qualquer modo, embora todo corretivo seja bem-vindo diante do que se poderia reconhecer, de comum acordo, como distorções de superfície ou provocadas por interferências externas ao métier do pesquisador - por exemplo alguma interferência decorrente de "militância", ou algum constrangimento por autoridades -, não fica claro por que se deveria crer que há um corretivo para o "problema" fundamental, ou seja, para o caráter interpretativo da subjetividade humana, caráter que

\footnotetext{
${ }^{21}$ Foi no sentido de assumir tal compromisso de discutir os conceitos de ciência e de religião num nível interdisciplinar e num contexto não-polêmico, mas dentro de uma área já existente que deveria, como se esperava então, envidar esforços de interlocução coletiva real - e não apenas nominal -, que ofereci minha primeira e única contribuição, até aqui, sobre estes tópicos (cf. n. 1 acima).

${ }^{22}$ Alguns deles, admitidamente, ainda se sustentam inclusive dentro de Departamentos de Ciências da Religião espalhados em nosso país, e trabalham na proximidade da filosofia ou da teologia. Ali ensinam, pesquisam e orientam na mesma área de estudos que seus colegas cientistas sociais, psicólogos etc., e é de se esperar que dessa proximidade surja algum fruto maior no futuro, mesmo que distante.
} 
talvez fique ainda mais visível, e pronunciado, justamente na esfera do religioso. Para formular a questão noutras palavras: pode-se esperar, com qualquer dose de realismo, que algum dia as ciências da religião sejam uma "ciência normal" sem que, com isso, a dimensão religiosa da religião e das religiões seja abolida pela explicação, explained away, por assim dizer? E sem que com isso se percam contribuições historicamente importantes como a da filosofia da religião e da própria teologia?

Ora, é óbvio que uma decorrência do caráter hermenêutico do estudo filosófico, e mesmo teológico da religião, é que estas duas formas de abordagem somente são, e só podem ser, "ciência da religião" em sentido amplo. Isso não é uma deficiência fundamental aos seus próprios olhos, e não fica claro porque o seria em geral. (Aliás, o presente autor crê ainda, talvez ingenuamente, que se alguém se permite ainda falar "em geral”, überhaupt, são justamente os filósofos!) Trata-se, em igual proporção, de uma vantagem fundamental, que certamente, como todas as vantagens, pode induzir e induz freqüentemente a erros. Todo o método de pesquisa, porém, e sobretudo nas ciências humanas, é falível, embora seja, ao menos em princípio, corrigível.

Teologia e filosofia incluem em seu estudo, obrigatoriamente e a partir de determinada tradição no caso da teologia, e eletivamente, na dependência de certas decisões gnosiológicas e ontológicas na filosofia, a pretensão de validade da religião. No caso da filosofia, tal validade pode ser fundamentada de várias maneiras. Dois tipos ainda "vivos", para espanto talvez dos cientistas de todas as coisas, são a maneira metafísica da fundamentação, por exemplo numa teologia filosófica testada discursivamente por instrumental lógico e analítico; ou numa abordagem mais calcada na validade transcendental das várias formas da vida subjetivo-intencional humana, dentre as quais a religião seria também candidata a constituir uma forma de vida autônoma, ao lado, por exemplo, do conhecimento, da moral e da arte.

Aqui, a filosofia não é uma disciplina simplesmente descritiva, não ao menos no sentido de descrever realidades "empíricas", equacionáveis com fenômenos bem específicos e mensuráveis, recolhidos, talvez, sob o guarda-chuva do "social"; ou, ainda, descrição de realidades não tão mensuráveis e mais pervasivas - pois que vinculadas à produção simbólica humana do sentido -, como no caso dos fenômenos recolhidos sob o guarda-chuva da "cultura". Mesmo a descrição filosófico-fenomenológica, embora busque abster-se de decisões e propostas de ordem metafísica, autodisciplinando-se pela epoqué, inclui em seu estudo o aspecto fundamental da consciência e da subjetividade ao atentar para a intencionalidade dos agentes, a qual produz e regula, ao menos segundo a tese fundamental - mas não a única - dos fenomenólogos, toda e cada concreção daquilo que é especificamente religioso.

Por isso mesmo teologia e filosofia da religião são, cada uma à sua maneira, "ciência da religião" em sentido amplo: por serem normativas, embora em sentido distinto do termo normativo. ${ }^{23}$ Ambas se ocupam, no mínimo dos mínimos, da validade

${ }^{23}$ Cf. LÖFFLER, Winfried. Einführung in die Religionsphilosophie. (Einführungen Philosophie.). Darmstadt: Wissenschaftliche Buchgesellschaft, 2006, p. 24, sobre o dilema da filosofia da religião: "Einerseits darf sie (a filosofia da religião, LHD) weder eine Religionswissenschaft im engeren Sinne sein (dann wäre sie in irgendeinem Sinne beschreibend und keine Philosophie), andererseits darf sie aber auch nicht in dem Sinne normativ sein, dass sie bestimmten Religionen verpflichtet ist (denn sonst wäre sie Theologie)." 
da religião. ${ }^{24}$ A teologia parte de uma revelação dada e de sua interpretação; pensa sistematicamente a religião de uma tradição específica dada como "a" religião. A filosofia leva a sério, ao menos prima facie e até melhor escrutínio, a pretensão de racionalidade da religião, obviamente não em um sentido restrito deste termo, ou num sentido irrefletido, porque já tornado habitus metodológico. Ela também pensa a religião em termos possivelmente universais, o que, embora tenha levado historicamente a vários problemas concretos na prática efetiva de filósofos $\mathrm{e}$ fenomenólogos da religião, não invalida no todo a possibilidade, por exemplo, de uma fenomenologia da religião revisada e revisável, ${ }^{25}$ nem a necessidade de um conceito simultaneamente não contra-intuitivo $e$ dotado de perfil próprio - da religião como tal. Isso é tanto mais o caso quando se pensa que tal conceito é indispensável para qualquer estudo que se pretenda sistemático e não desordenado, ou seja, marcado por empirismos ingênuos e compilatórios, para os quais, ao final, qualquer coisa - inclusive nada - pode ser "religião", bastando, para pôr um exemplo risível, que alguém se "autodeclare" como representante de determinada "religião", mesmo que seja somente a dele.

Ainda sobre a filosofia da religião, bem diz P. Tillich:

La filosofía de la religión es una de las ciencias culturales o normativas. Establece, en una síntesis creativa y generadora, aquello que puede considerarse como válido en matéria de religión. Emplea en su construcción normativa los materiales que proveen la historia de las religiones, la psicología de la religión y la sociología de la religión. Pero no es idéntica, sea en parte o en su totalidad, con ninguna de estas tres ciencias empíricas. Su tarea no consiste en considerar aquello que la religión es (Seiendes) sino aquello que debe ser (Gültiges). La información fáctica sirve como material para su obra de construcción, pero no es la meta de su trabajo. $^{26}$

\footnotetext{
${ }^{24}$ Cf. n. 7 acima, em que buscou-se excluir a noção, que de fato bem descreve algumas formas resistentes e surpreendentemente de novo atraentes, para alguns, de fazer teologia, segundo a qual a teologia basearse-ia numa regulação estranha e autoritária, em última análise num poder ou imposto, ou aceito por algum tipo de sacrifício intelectual. A acepção de "normativo" que aqui se discute nada tem a ver com "dogmático". Tampouco tem a ver, ao menos num primeiro momento e no sentido usual destes termos, com a gama de conotações associadas a "ético", "moral", etc. O normativo é o válido no sentido de uma regulação necessária mas interna, e portanto livre.

${ }^{25}$ A pergunta se "o adeus da ciência da religião à fenomenologia da religião" seria um "até nunca mais" é respondida no negativo, com evidências relativas especificamente ao cenário europeu-alemão pelo artigo bastante ponderado de Brandt, referido acima; cf. BRANDT, As ciências da religião numa perspectiva intercultural, p. 129-30.

${ }^{26}$ Paul TILLICH, Filosofía de la religión, Buenos Aires: Ediciones Megápolis, 1973, p. 14. Pode-se ir mais longe e perguntar se alguma abordagem empírica da religião pode, já metodologicamente, e muito mais na prática real de seus pesquisadores, prescindir totalmente de elementos normativos. Talvez alguns praticantes destas abordagens gostariam de crer e que se cresse nisso; mas seria ingenuidade pensar que disciplinas como a sociologia e a psicologia da religião são puramente empíricas, e que estão do lado dos "fatos" desvendados pela ciência. A rigor, qualquer tipo de pesquisa da religião pode, em princípio, ou pressupor (como um habitus), ou então levar a questões que são normativas no sentido acima exposto. Se o método disso pudesse se livrar, não poderia o pesquisador que o usa! Pois qualquer pesquisa da religião feita, como é de se esperar, por um pesquisador, pressupõe uma ou mais teorias acerca da religião e do mundo. E toda teoria (sobre a religião) possui um componente de interesse filosófico e filosóficoreligioso.
} 
Ao leitor acostumado com o viés descritivista e contextualista da abordagem mais típica da cultura - resultante da confluência de antropologia e sociologia ${ }^{27}$-, pode parecer estranha a identificação, proposta por Tillich, entre as ciências culturais e a idéia de normatividade, entendida como validade (Gültigkeit). Como no caso da filosofia da religião enquanto possível "ciência da religião", também aqui somente pode tratar-se de ciência cultural em "sentido amplo". ${ }^{28}$ Já a tese de que a filosofia da religião seria construtiva $^{29}$, e não apenas descritiva, ao marcar bem o limite entre filosofia e as ciências da religião, provavelmente espante menos e agrade mais: poderiam inclusive pensar alguns que ela garantiria, aos cientistas da religião, uma autoridade e objetividade maiores no discurso sobre a religião, afastando de vez os fantasmas da "metafísica", do "essencialismo" e da "teologia".

Ledo engano! Sabidamente, os critérios de objetividade em filosofia são sempre mais amplos - mas nem por isso mais frouxos - daqueles das ciências empíricas, e os filósofos costumam pensar que os últimos precisam, além de ser aplicados com êxito quantitativo, ser ainda constantemente justificados dentro de um esforço teórico mais abrangente. Noutras palavras, critérios de objetividade em geral precisariam ter revelados seus próprios pressupostos sobre o que é validade, e, sem deixar de serem aplicados, ser simultaneamente contemplados com mais argumentação e mais "estranhamento", tão recomendado noutras situações.

\section{Religião, Teologia e Filosofia da Religião}

Uma pergunta que intriga a todos os pesquisadores sérios da religião, mesmo os que já tenham tomado decisões de tipo existencial não tipicamente religiosas, quer prévia ou simultaneamente a sua prática intelectual, diz respeito à religião enquanto expressão espontânea de uma vida consciente de si. Para o homem religioso, entendido em algum sentido como homem de "fé", a religião possui uma inegável dimensão de autonomia ou independência diante de outras formas de vida e de outros sistemas de orientação. Outrossim, ela se constitui num vetor de intencionalidade dirigido a um sentido que, de um ou de outro modo, se dá, para a maioria ou a totalidade dos homens

\footnotetext{
${ }^{27}$ Para uma brevíssima apreciação, cf. CRUZ, A persistência dos deuses, especialmente 54-60.

28 A idéia de (qualquer) "ciência" em "sentido amplo" parece estar ligada, no passado próximo, ao destino do conceito de Wissenschaft no idealismo alemão e naquilo que dele foi preservado na seqüência, sobretudo na sistematização de Wilhelm Dilthey. Para mais detalhes, embora obviamente insuficientes desta discussão, cf. DREHER, Ciência(s) da Religião: Teoria e Pós-Graduação no Brasil, p. 161-65.

${ }^{29}$ Anote-se, de passagem, a dificuldade geral da fenomenologia, especialmente em E. Husserl, com a idéia de construção, por apontar esta para a atitude explicativa espontânea tão comum na história da filosofia, tanto na metafísica como na teoria do conhecimento. Esta dificuldade com a idéia de construção parece em geral marcar o programa, admitidamente difuso, dos fenomenólogos da religião, o que torna até difícil tachá-los de "teólogos" ou "metafísicos" no sentido mais estrito destes termos. Por isso mesmo eles recorrem à descrição, mas não à descrição empírica que marca os métodos das ciências "duras" da religião, já eivados de pressupostos filosóficos (inexaminados) que pré-definem, eles mesmos, a essência da religião sem deixá-la aparecer do modo requerido, rotulando, na seqüência, qualquer tentativa deste tipo como "essencialismo", entendendo por isso, erroneamente, a fixação geral, e não em um ou outro autor relapso, de um "algo" aferível atrás das coisas. Isso, porém, está a milhas de distância do que disseram E. Husserl e os próprios fenomenólogos da religião, ao menos enquanto se abstiveram de construir, a saber, de desenvolver uma filosofia da religião com base nos achados da fenomenologia.
} 
tipicamente religiosos, como objetivo e transcendente em algum sentido destes termos. Ora, qualquer descrição adequada desta intencionalidade deve pelo menos deixar em aberto suas pretensões de validade e verdade, e não simplesmente considerá-las como resultado de alguma forma de menoridade, ${ }^{30}$ como uma "postulação" no sentido fraco da palavra, ou seja, como projeção ou ficção psicológica, social ou cultural que simplesmente se elimina ao explicá-la por outros, e supostamente melhores, expedientes.

Considerar a pretensão do homem ou dos homens religiosos significa pelo menos sopesar a hipótese de que - como já se afirmou - a religião possa ser, ademais, uma esfera própria e independente de validade no âmbito da experiência humana. Como tal, achados de natureza simplesmente empírica, por exemplo científico-social ou psicológica, não podem, por si só ao menos, isto é, sem referência a esquemas conceptuais mais amplos que explodem os limites estritos da prática científica, invalidar tal pretensão, reduzindo-a a outras esferas de validade, admitidamente também dotadas de singularidade e originalidade no tocante a todas ou algumas de suas feições invariáveis. Ou, pior ainda, reduzindo-a a nenhuma esfera de validade, por hipótese a algum tipo de brotamento contingente da natureza que se exprime no psiquismo ou na dimensão social.

Já no que tange à questão da pretensão de verdade, a demanda é ainda maior. Aqui torna-se necessário, em algum sentido, explicitar as próprias convicções filosóficas de fundo, das quais ninguém, a rigor, está livre - nem os trabalhadores da vinha, aqueles que apenas aplicam e praticam um método estabelecido no campo para colher resultados a cada nova safra. A questão da verdade da religião em filosofia, por exemplo, foi resolvida de várias maneiras, e há todo um elenco de perspectivas sobre o tópico, como é sabido. Para citar apenas uma linhagem de pensadores: obras clássicas da filosofia, como as de B. Pascal e S. Kierkegaard, representam no geral uma mesma posição - que no momento não é exatamente a representada por este autor - que estaria bem próxima de ser classificada como teológica no sentido não-eclesial do termo. Eles desenvolvem, a partir da explicitação de um ato vital e existencial para o qual vêem boas razões e nenhuma alternativa realmente viável, não só uma filosofia da religião, mas formas bem típicas de filosofia religiosa, incluindo aquele ato vital e existencial, de maneira tão filosoficamente controlada quanto possível, em sua atividade intelectual.

Nas propostas de filosofia religiosa coloca-se, bem claramente, a passagem da discussão da validade à verdade da religião, com uma solução evidentemente marcada pela admissão consciente de pressupostos. Só que, numa concepção mais robusta de filosofia, às vezes a circularidade é inevitável nas questões centrais, e trata-se então de defender a maior ou menor qualidade dos pressupostos por contraste com a concorrência, e por apelo a uma série de fatores internos e externos ao próprio discurso e argumentação. Por outro lado, que exista um método científico, sobretudo aplicado às

\footnotetext{
${ }^{30}$ A metáfora em CRUZ, A persistência dos deuses, p. 60, é interessante, embora lá o autor se refira somente à abordagem entendida, grosso modo, como "culturalista", a qual estimularia a atitude distanciada - porque não leva em conta justamente a nossa própria dimensão subjetiva e normativa - de pretensos "adultos que observa(m) um grande número de crianças brincando muito a sério com suas religiões".
} 
coisas humanas, isento de pressupostos, está ainda por ser provado. E, a não ser por razões práticas e de crítica ideológica, cuja validade tem então que ser provada ou assumida existencialmente, à parte e ao lado do estudo científico da religião, restaria demonstrar de igual modo com que direito uma ciência que, por sua natureza científica, deveria coibir todos os laivos de exercício filosófico e metafísico, por vezes parece abandonar esta auto-restrição sem reconhecer tal abandono, fazendo-se passar ainda por ciência.

Mas voltemos a um ponto já indicado no título desta seção, com o fito de clarear a relação entre religião, teologia e filosofia. Aqui é preciso acentuar que o discurso religioso nunca é o próprio ato vital. A vivência do homem religioso, mesmo a dos místicos, ${ }^{31}$ se expressa em seu discurso, mas não é ela mesma totalmente redutível a ele. ${ }^{32}$ Se a teologia é, em algum sentido, discurso do homem religioso ou de uma dada coletividade humana religiosa, localizada espaciotemporalmente, então a teologia não é diretamente religião, ${ }^{33}$ e sim discurso segundo, refletido, que, como discurso, configura um nível menos originário. É bem verdade que o menos originário pode definir a interpretação da vivência e mesmo redefinir vários de seus aspectos, até constituir aquilo que originalmente, numa acepção ainda propriamente religiosa, era o dogma enquanto a "gramática básica", meramente autodescritiva, de uma religião. Desde há muito a teologia se configurou, assim, quer como auto-expressão ou auto-exposição didática da própria “fé"; quer já como apologética, diante dos desafios da razão e do mundo; ${ }^{34}$ quer como dogmática, diante do que era percebido internamente como

${ }^{31}$ OTTO, Rudolf. O Sagrado. Trad. João Gama. Lisboa: Edições 70, 1992 [1917], p. 10: “...o misticismo ... é particularmente diserto."

${ }^{32}$ Daí, a meu ver, a insuficiência de uma abordagem centrada simplesmente no aspecto simbólicolingüístico das religiões. A noção de que a religião se expressa numa linguagem e em interação com outros sistemas simbólicos é sumamente importante, mas tende com freqüência a desconsiderar a pretensão de universalidade dos atos ling üísticos especificamente religiosos justamente qua atos, e sua possível fundamentação numa dimensão não-lingüística e não-psicológica, porém transcendental. Talvez uma razão de seu sucesso tenha sido o cultivo oposto de uma definição de religião demasiadamente próxima da vivência, e ligada a alguma forma, só marginalmente filosófica e tendencialmente frouxa do ponto de vista teórico-cognitivo, de philosophia perennis.

33 É claro que mesmo esta distinção é moderna; ela aparece já na teologia protestante iluminista ("neologia") do século XVIII, em J. S. Semler, e é retomada magistralmente por Schleiermacher. Provavelmente ela tenha, em parte, sido responsável pelo processo de "antropologização" da religião no período posterior, embora não tenha sido esta a intenção original. Em Schleiermacher fica claro, em contraste com L. Feuerbach, a intencionalidade da consciência religiosa, que em sua pré-racionalidade (religião é "sentimento" e "intuição", "gosto pelo infinito") passa, num momento posterior, a justificar-se como uma esfera possível de validade para dar conta daquilo que, sem ser propriamente "experiência" no sentido kantiano - Kant, havia, aliás, ao limitar a esfera do conhecimento, deixado aberta mais de uma brecha para a "fé" ou a religião ("racional") -, é um elemento incontornável da consciência e uma constante antropológica básica.

${ }^{34}$ Formas de discurso como a "teologia da cultura", e talvez mesmo uma "teologia da ciência", são exemplos atuais disso, sem necessariamente exercerem uma função de apologética eclesial. No geral, buscam mostrar a vitalidade e razoabilidade da concepção cristã do mundo, entendida como uma força histórica e auto-interpretativa, e por isso mesmo irredutível, enquanto princípio lingüístico criativo e expansivo, às primeiras formulações da fé estabelecidas no mundo antigo - tão diferente do nosso. Tratase daquelas formas de teologia que levam bem mais em conta as concepções filosóficas e científicas mais recentes em suas implicações para os conceitos de "experiência" e "razão" como critérios possíveis do 
variação suficiente para estabelecer dissensão comunitária e a instauração de um novo princípio religioso concorrente - ou, mais tarde ainda, mormente na modernidade e numa história que ainda não terminou, como a reação conservadora ${ }^{35}$ diante de um mundo desvinculado daqueles que se crê serem seus próprios princípios religiosos constitutivos.

Nisso tudo se pode perceber que a palavra "teologia" é mais uma dessas que possuem várias acepções, mas que curiosamente numa única delas causa horror a sensibilidades forjadas quer por alguma dose de ignorância, quer por uma mescla complexa e mal congeminada de linguagem pré-reflexiva, ideologia e apreciação exógena do mundo religioso. Com efeito, a partir da perspectiva balizadora deste trabalho seria possível inclusive propor uma definição formal e unicamente negativa de "teologia", a saber: um discurso intelectualmente autônomo e que, enquanto discurso, não tolera "argumentos de autoridade" nem ingerências de ordem político-institucional, como p. ex. as de um "magistério" - seja qual for sua proveniência, eclesiástica ou não -, mas que mesmo assim ousa falar do sujeito-objeto da religião ${ }^{36}$ sem intimidar-se por ditames provenientes quer de preconceitos pouco científicos, quer do que se julga ser "politicamente correto" em ambientes acadêmicos marcados seja pelo confessionalismo religioso, seja pelo positivismo como cosmovisão inconfessa. ${ }^{37}$

Voltando ao que mais importa. É razoável dizer que a possibilidade de uma teologia, assim como de uma fenomenologia da religião, de uma filosofia da religião e mesmo das demais ciências da religião está ancorada numa mesma imagem de círculos concêntricos, que é sempre rearranjada e valorada de acordo com a perspectiva do pesquisador e/ou do método em que foi treinado - junto com os pressupostos filosóficos neles apenas implícitos ou tematizados. Faz-se, aqui, referência à imagem e à distinção talvez já clássica mas oxalá não ultrapassada, no estudo da religião e das religiões, entre o mundo vivencial, o mundo ideativo (ou representacional) e o mundo fenomênico da religião. ${ }^{38}$

\footnotetext{
fazer teológico, deixando mais de lado outras normas tradicionais da teologia, como a Escritura e a Tradição.

35 Este termo não haure, aqui, nenhuma inspiração no senso comum. Tampouco possui qualquer conotação eclesiológica ou politológica, mas somente histórico-descritiva.

${ }^{36}$ Este conceito está dado para os teólogos enquanto teólogos, e implica discutir e levar a sério, na pesquisa, conceitos como "revelação" e "salvação". Com efeito, é de se perguntar se toda e qualquer filosofia da religião pode levá-los a sério, embora seja curioso notar que também filósofos ocasionalmente se digladiaram com eles. Quando isso ocorreu, a ocupação com tais conceitos foi filosófica-fundamental, isto é, "metafísica". Dois exemplos de pensadores que, de alguma maneira mais ou menos livre, lidaram com estes conceitos, são o "budista" A. Schopenhauer (salvação, Erlösung) e F. W. J. von Schelling (revelação, Offenbarung).

${ }^{37}$ Não se faz aqui referência ao positivismo de A. Comte, porque então haveria que dar conta, ainda, de sua contradição performativa, a saber, o retorno a um discurso religioso em sentido amplo. (Uma maneira usual de dar conta desta contradição foi apontar para algum tipo de delírio da idade mais avançada, resolvendo-a psicologicamente.) Pensa-se, isto sim, no positivismo como princípio informativo das ciências e que, não raro, permaneceu como a infraestrutura - já uso o termo em sentido figurado - de inúmeras, não necessariamente de todas, variações daquele marxismo que se tornou o coiné em mais de um departamento em ciências humanas, econômicas e sociais.

38 Cf. o artigo de L. RICHTER, Religiöses Erlebnis. In: Die Religion in Geschichte und Gegenwart $(=R G G)$, 3. ed. Tübingen, J.C.B. Mohr (Paul Siebeck), 1956-1965, v. 2, p. 569.
} 
Salta aos olhos que, dependendo da compreensão do que seja a teologia, ou ela se concentra, como atividade mais ou menos autônoma, nos círculos da vivência e das idéias de uma religião histórica e específica, assumindo, no geral, não só a validade, mas também a verdade daquela vivência, normalmente como captação de uma revelação original que já se consolidou definitivamente em fé e deve ser continuamente reinterpretada desde dentro, num processo histórico-apropriativo que é fundamentalmente lingüístico; neste sentido, a esfera de manifestação empírica, espaciotemporal da religião, é tida como livre expressão, que requer livre adesão, daquela captação originária.

Ou então a teologia se concentra na tarefa de legitimar, dentro e ocasionalmente fora, a doutrina e a práxis de um elemento específico da manifestação da religião em seu estado atual. Este elemento é normalmente a "igreja" ou comunidade religiosa que se baseia, para sua existência em um meio percebido como mais ou menos hostil e objeto de missão, numa observância mais ou menos estrita de códigos ou leis tidos como relativamente infalíveis em decorrência de sua origem nalgum tempo fixada autorizadamente. Aqui, a esfera de manifestação empírica, espaciotemporal da religião, é tida como depósito e corporificação daquela captação originária, que igualmente espera livre adesão, mas se afirma como verdade objetiva independente desta.

Trata-se, obviamente, de tipos ideais, que grosso modo refletem, para qualquer leitor atento, os princípios protestante e católico do cristianismo; este trabalho, porém, não quer reduzir as formas possíveis de compreender a teologia, mas apenas dirimir alguns preconceitos quanto à sua compreensão. Como já sugerimos, a extensão da discussão sobre "teologia" levando em conta outras tradições religiosas ${ }^{39}$ pode ampliar o conhecimento e nossa compreensão desta atividade tão próxima da religião. Embora seja complexa, tal extensão não deve ser em princípio impossível, uma vez que aquilo que intuitivamente chamamos de religiões em geral inclui discursos sobre "revelação" e "salvação".

Também no caso da fenomenologia e da filosofia da religião existe uma concentração nos círculos da vivência e das idéias da religião, preocupando-se a fenomenologia da religião tendencialmente com a primeira, e a filosofia da religião tendencialmente com a segunda. À diferença do que ocorre com a teologia, porém, as religiões históricas e específicas não são aqui tidas como normativas, mas normalmente como material contingente para o desvelamento de estruturas específicas ou mais gerais quer de sentido, quer de validade ou verdade. As disciplinas filosóficas - e este é também o caso da fenomenologia da religião enquanto tal e por princípio - preocupamse com os elementos necessários da experiência religiosa como tal, ou, noutra linha de abordagem, com a defensabilidade ou indefensabilidade das proposições religiosas ${ }^{40}$. Estamos aqui basicamente nos âmbitos da discussão gnosiológica e metafísica, com ênfase na validade e sustentabilidade de formas de experiência do mundo, de conhecimento e linguagem, sempre em correlação com critérios também gerais de experiência, linguagem e conhecimento.

\footnotetext{
${ }^{39}$ Cf. n. 2 acima.

40 Trata-se de considerar a razoabilidade destas proposições, sua compatibilidade com conceitos mais gerais ou alternativos de racionalidade.
} 
Mas é também possível, e cada vez mais encontradiço num âmbito marcado pelo pluralismo entendido como incomensurabilidade de linguagens, que a fenomenologia e a filosofia da religião se dediquem à elucidação de estruturas de sentido e à análise da gramática e das proposições de tradições religiosas específicas, às vezes sem nenhum objetivo concreto, às vezes a serviço do diálogo inter-religioso, às vezes, ainda, com interesse mais apologético e em maior cumplicidade com a teologia de uma tradição específica. Mas, como a maior parte dos filósofos bem sabem, isso por si só, sem o apoio de boas razões em contrário, não desautoriza qualquer discurso filosófico.

Quanto ao mundo fenomênico ou da "manifestação" empírica da religião: é neste último, principalmente, que a religião se cristaliza em formações empíricas, como comportamentos sociais padronizados e instituições, que nem sempre a própria religião continua a condicionar ou determinar em toda sua extensão. É concebível mesmo que alguns destes fenômenos nem decorram, em seu cerne, de interesse especificamente religioso. Exemplos atuais poderiam ser colhidos de nossa época, marcada, por exemplo, por grande interação entre o mundo religioso e o mundo da economia e da mídia - interação que não implica, necessariamente, que a "colonização" da vivência e do interesse religiosos seja uma prova quer da sua inexistência, quer, por um juízo global e sem qualificações, da sua inautenticidade.

Seja como for: boa parte dos debates epistemológicos nas ciências da religião, especialmente no que diz respeito ao conceito operacional de "religião" - mas também ao quase sempre velado conceito definitivo, "normativo" da mesma - reflete decisões e discordâncias sobre o estatuto dos mundos vivencial e fenomênico da religião. Desde há muito se tem perguntado, no geral e na filosofia da religião em particular, acerca da relação entre os vários círculos ou "mundos" da religião e sobre que forma de hierarquia vige (ou deve viger) entre eles. Grande parte dos filósofos, nessas disputas, geralmente se recolhe ao mundo ideativo da religião; acham eles que aí é que se decide aquilo que se pode decidir em última análise, com o devido acompanhamento de um ato vitalexistencial do qual em geral estão dispostos a falar.

Os filósofos podem, por hipótese, lembrar que as teses de que a religião exibiria uma "dependência" ou uma autonomia apenas "relativa" diante da esfera sociopolítica ou cultural, ou de que haveria, antes, um caminho de ida e volta, de dupla determinação ou influência entre estas esferas, podem ser bons instrumentos heurísticos e metodológicos na prática científica. Elas podem, de fato trazer grandes resultados, sobretudo a primeira, que satisfaz mais de perto a ansiedade baconiana do "saber que é poder" radicado em boa parte de nossa ciência ordenada à tecnologia, também a de tipo social. Trata-se de dominar o objeto, mesmo quando ele parece fugir a galope, e desancar os ídolos que só estorvam nosso conhecimento dos corpos naturais e artificiais. Mas tais teses ainda deixam em aberto a questão referente a que se entende por religião, e com que boas razões, além daquelas meramente metodológicas - ou seja, para o trabalho na vinha - privilegia-se a autonomia quase absoluta de outros objetos que, por estarem (supostamente) mais radicados na esfera empírica, como "cultura" e "sociedade", pareceriam estar, eles sim, além de qualquer suspeita quanto a sua densidade e mesmo validade.

Dessa breve incursão no campo das relações possíveis entre religião, teologia e filosofia da religião - incluída, nesta, a abordagem fenomenológica, ao menos em algumas de suas expressões - pode-se aprender, até melhor instrução, algumas coisas. 
Primeiro: dissipa-se a ignorância, por vezes preconceituosa e encontrada mesmo entre filósofos da mais elevada competência e sutileza dialética, que leva a identificar grandezas tão distintas como "teologia" e "igreja". Descobriu-se que a teologia, embora possa ser, e de fato seja também "teologia eclesial"," tem mais de um sentido. Ou, parodiando Aristóteles, "a teologia se diz em muitos sentidos." 42 Não se chegou a mencionar, por exemplo, que do ponto de vista estritamente filosófico resiste ainda bravamente uma "teologia filosófica", geralmente ligada à metafísica ${ }^{43}$ - mais recentemente buscando na lógica e na filosofia analítica os recursos para seus empreendimentos -, às vezes também à ética. Ora, a teologia filosófica é a formulação própria de uma abordagem que precede a moderna filosofia da religião; já esta é, simultaneamente, uma disciplina filosófica num sem-número de abordagens. ${ }^{44}$

Segundo, aprofundou-se a constatação de que a teologia e a filosofia (e, por extensão, a filosofia da religião) envolvem, em suas respectivas definições, certa problematicidade constitutiva. Sobretudo em filosofia é possível estar em várias partes, representar os mais distintos e móveis enfoques sobre objetos também relativamente

\footnotetext{
${ }^{41} \mathrm{O}$ teólogo K. Barth foi, no protestantismo, o expoente na defesa desta concepção, em sua disputa com a teologia liberal neoprotestante - aquela cuja concepção de teologia foi marcada pelas influências da pesquisa histórico-crítica, de Kant, Schleiermacher e Hegel, e do historicismo. No geral, a concepção da teologia como atividade estritamente eclesial é a concepção da Igreja Católico-Romana, embora já desde o século XIX - cf. a "Escola Católica de Tübingen" e o modernismo católico da virada do século XX -, e não só a partir das teologias progressistas na esteira do Concílio Vaticano II, tenha havido certa concorrência a esta concepção.

${ }^{42}$ LÖFFLER, Einführung in die Religionsphilosophie, p. 23, oferece sua própria taxonomia, distinguindo entre o sentido "institucional-organizativo", o sentido "objetivo" e o sentido "subjetivo" de teologia, apontando ainda para a disciplina puramente filosófica, a "teologia filosófica" no sentido por nós indicado a seguir e por ele pensado na proximidade estrita com a metafísica ou "teoria da realidade" (24).

${ }^{43} \mathrm{O}$ termo "metafísica" é sabidamente complexo e sempre relativo aos contextos específicos de discussão filosófica. [Para uma visão geral das principais formulações do conceito, cf., p. ex., o artigo de W. SCHULZ, Metaphysik. In: Die Religion in Geschichte und Gegenwart $(=R G G)$, 3. ed. Tübingen, J.C.B. Mohr (Paul Siebeck), 1956-1965, v. 4, p. 908-913.] Anota-se aqui, porém, que o próprio Kant, chamado em sua época de "demolidor da metafísica", elaborou "metafísicas" críticas do "conhecimento" e dos "costumes". No contexto desta última, a partir de uma doutrina dos postulados e como extensão de sua teoria ética, propôs uma teologia filosófica inédita, fundada em princípios da razão prática. É bem verdade que, na seqüência, esta teologia filosófica baseada na ética foi duramente criticada, no nível interno e externo, p. ex. por J. G. Fichte, e, a partir dele, em outros idealistas alemães (que tinham outra concepção teológico-filosófica, mais próxima de um "panteísmo" profundamente revisado) e na filosofia posterior - p. ex., indiretamente, em Nietzsche, mas inclusive no ficcionalismo de H. Vaihinger ("Philosophie des Als Ob"), que torna a intenção de Kant já quase irreconhecível.

${ }^{44}$ Para o todo cf., p. ex., o artigo de KODALLE, KÜHNLEIN, Religionsphilosophie, p. 343-367. Os autores distinguem corretamente entre filosofia da religião como disciplina filosófica estrita e como "propedêutica de uma determinada forma histórica de teologia (evangélico-protestante ou católica)" [p. $\left.344, n^{*}\right]$, seguindo a prática usual de caracterizar a filosofia como disciplina que, embora surja sempre de um contexto histórico, não reconhece a normatividade de fatos históricos (como são - parcialmente ao menos, por admissão religiosa - revelações e suas tradições). A mesma distinção pode ser feita no tocante ao termo "teologia filosófica", já que, numa tradição acadêmica protestante ligada especificamente ao legado de Schleiermacher, o termo muitas vezes é usado em sentido filosoficamente mais fraco, para distinguir aquilo que se poderia entender por uma disciplina em parte tomada de empréstimo à filosofia, em parte interna à teologia como saber basicamente histórico: trata-se da "doutrina teológica dos princípios", dos "prolegômenos à teologia" ou, numa linguagem católico-romana, da "teologia fundamental", complementada, no protestantismo, pelas teologias "histórica" e "prática".
} 
distintos e móveis. (Esta mobilidade da filosofia faz dela um alvo relativamente difícil de ser atacado por outros discursos, um alvo móvel, a moving target; mas por causa da sua notória complexidade, é paradoxalmente fácil interpretá-la como um pato sentado e vulnerável, a sitting duck.) Outrossim, dependendo de onde se está, a filosofia pode aproximar-se ou distanciar-se mais do mundo da religião vivida. Embora não sejam religião, teologia e filosofia diferenciam-se das ciências à medida em que, tendencialmente ao menos, exigem dos seus praticantes a mais extensa forma de honestidade intelectual, aquela que envolve tematizar, por um dever de vocação, sua orientação geral sobre questões básicas da vida. Trata-se, aqui de uma exigência quase objetiva, e não de uma atitude que se poderia eleger ou não. De fato, vimos que ambas são, quando não se transformam em exercícios totalmente triviais e meramente profissionais, ato vital e existencial, sem nenhum prejuízo da neutralidade e da autocrítica possíveis. Aqui, reenviar questões básicas e as respectivas propostas de solução para uma esfera íntima e privada, deixando de tematizar discursivamente as convicções de fundo, mesmo que provisórias, não é necessariamente produtivo para o avanço do saber - admitidamente: destes tipos de saber.

Terceiro, descobriu-se que embora não seja adequado dizer que é somente $o$ mundo vivencial da religião que importa às três disciplinas, parece que há pelo menos tantas razões boas quanto ruins para levar a sério, em algum sentido, esta dimensão da religião. Pois é a partir dela, em última análise, que se permitiria à filosofia - e mesmo a qualquer ciência da religião que leve a sério sua autodenominação! - captar em algum sentido a especificidade de seu objeto. É notório, por exemplo, que quando a filosofia se concentra no mundo ideativo da religião, imediatamente corre o risco de diluir o discurso filosófico sobre a religião num discurso metafísico ou gnosiológico mais geral, que pode ou não incluir alguma formulação clássica da teologia filosófica (teísmo, panteísmo, ateísmo - só para mencionar algumas delas). Já os conteúdos da vivência religiosa são mais difíceis de traduzir em conceitos imanentes ao discurso propriamente filosófico.

Assim, ganha maior acúmen a pergunta relativa a se ainda se justificaria ou não, hoje, no seguimento e quiçá no aperfeiçoamento e/ou modificação de uma indagação originalmente kantiana e transcendental, a localização de estruturas puramente formais, ou seja, a priori, de validade que regulariam a constituição da experiência religiosa em geral. ${ }^{45}$ Num outro registro, este nitidamente fenomenológico, a mesma pergunta pode ser feita acerca de se ainda prevalecem ou não boas razões para defender a especificidade dos atos intencionais da consciência religiosa, privilegiando a questão do sentido, e também aqui sempre deixando em aberto, e para um segundo momento de opcional formulação filosófico-geral, a questão da existência ou da realidade do objeto religioso, de sua possível natureza e de sua relação com o mundo histórico e fenomênico das religiões. Já num terceiro registro, pode articular-se a pergunta, algo mais modesta, se a especificidade do jogo de linguagem religioso é de fato compatível, direta ou indiretamente, com a tese da independência da religião (de sua Selbständigkeit, no sentido de a religião "manter-se por sua própria conta", sem depender, necessariamente, de orçamentos alheios).

\footnotetext{
${ }^{45}$ Cf. p. ex. n. 16 acima.
} 


\section{Considerações Conclusivas}

A bem da verdade, as últimas considerações deste trabalho não são nem conclusivas, devido à característica de exposição relativamente livre, nem, muito menos, concludentes. Querem apenas inspirar debates futuros, que podem ser acalorados ou não, que podem envolver várias estirpes de estudiosos da religião, ou só aquelas que se acham na proximidade da orientação, reconhecidamente bastante geral e insuficientemente perfilada, do horizonte aqui buscado. Unicamente a direção futura deste debate, junto com seus resultados mais ou menos provisórios, poderão mostrar, por exemplo, se a filosofia da religião continuará a ser reconhecida como "ciência da religião em sentido amplo", ou se acabará por ser destituída de seu posto até então, aparentemente ao menos, indispensável nos estudos da religião enquanto área acadêmica própria. Neste contexto, ficará claro, entre outras coisas, se alguém precisa mais de alguém, e quem precisa mais de quem: se as ciências da religião da reflexão filosófica, ou se a filosofia da religião das ciências da religião.

De igual modo, é unicamente a direção futura deste debate que irá determinar se a fenomenologia da religião permanecerá candidata ao posto de possível princípio sistematizador de uma futura ciência da religião, ou se deverá, antes, configurar apenas, como agora, uma disciplina entre outras das ciências da religião. Ou, numa terceira hipótese - o que, diga-se de passagem, já seria suficientemente digno e relevante - se ela permanecerá apenas um tipo característico de filosofia da religião, em forma pura ou numa síntese com outros, ao qual os filósofos da religião poderão sempre voltar, do mesmo modo que podem sempre voltar, de algum modo, aos pré-socráticos, a Platão ou a Aristóteles sem por isso já se sentirem fora de moda.

Em algum momento acima, afirmou-se acima a indispensabilidade metodológica ou operacional do conceito de religião. Esta indispensabilidade, atestada entre vários outros por J. Z. Smith ${ }^{46}$, parece tornar um pouco fantasiosa a idéia de que o objeto da filosofia da religião, ou mesmo das ciências da religião em sentido estrito, poderia ser simplesmente "as religiões", por mais que isso seja interessante do ponto de vista de uma nova impostação ética para o estudo das religiões. Só que, como já foi objeto de alusão acima, as boas intenções nunca são suficientes para constituir um saber, menos ainda um campo de saber. (Para não falar da vigência de pressupostos concomitantes, às vezes embalados em tinturas "pós-modernas", que reivindicam pluralismos do tipo que já supõe a incomensurabilidade absoluta, não só de um ponto de vista material, mas também formal, de culturas e formações históricas específicas.)

\footnotetext{
${ }^{46}$ SMITH, Jonathan Z. Religion, Religions, Religious. In: Mark C. TAYLOR (Ed.). Critical Terms for Religious Studies. Chicago: University of Chicago Press, 1998, p. 281-82, conta a seguinte historinha interessante e tira sua "moral" para questão que nos interessa: "It was once a tactic of students of religion to cite the appendix of James H. Leuba Psychological Study of Religion (1912), which lists more than fifty definitions of religion, to demonstrate that 'the effort clearly to define religion in short compass is a hopeless task' (King 1954). Not at all! The moral of Leuba is not that religion cannot be defined, but that it can be defined, with greater or lesser success, more than fifty ways. Besides, Leuba goes on to classify and evaluate definitions. 'Religion' is not a native term; it is a term created by scholars for their intellectual purposes and therefore is theirs to define. It is a second-order, generic concept that plays the same role in establishing a disciplinary horizon that a concept such as 'language' plays in linguistics or 'culture' plays in anthropology. There can be no disciplined study of religion without such a horizon."
} 
Insistiu-se também em que não se trata apenas de que, a partir de uma abordagem filosófica, as definições operacionais de religião não bastem. ${ }^{47} \mathrm{~A}$ filosofia tem sua própria tarefa crítica diante das ciências, pois a recusa em delinear definições mais definitivas ou substantivas de religião já esconde, às vezes, sua presença dissimulada. Conceitos normativos que não se apresentam como tais têm às vezes impacto profundo sobre os conceitos ou definições operacionais ou puramente metodológicas.

$\mathrm{Na}$ verdade, é argüível já serem conceitos e definições de religião mais que operacionais, e, portanto, "definitivos", aqueles que em termos gerais se costumam denominar de "essencialista" e "funcionalista"48; eles constituíram e constituem definições e métodos característicos de pesquisa; porém, à medida em que se faz o esforço de abstrair seus elementos articuladores, implicam posições mais fundamentais no nível da explicação já propriamente filosófica da religião. Algo semelhante se poderia dizer da diferenciação entre definições teológicas e antropológicas da religião, que configurariam, segundo mais de um autor, tipos fundamentalmente distintos. ${ }^{49}$ Todos estes conceitos e definições, e não só alguns deles, padecem no fundo da mesma enfermidade do "universalismo". Ou seja: eles exibem a tendência a universalizar uma posição, um conceito normativo de religião, porque em algum nível eles exibem uma pretensão de universalidade a partir da parte que investigam. Mas é justamente à filosofia que cabe elucidar estar pretensões de conceitos aparentemente inocentes, aparentemente isentos de carga normativa.

Outro elemento acentuado e que caberá elucidar mais no futuro foi a distinção e a possível complementariedade, para estudos em filosofia e eventualmente nas ciências da religião - entre descrição fenomenológica e a tradicional afirmação, em várias abordagens filosóficas, do aspecto de validade implícito na experiência religiosa. Este aspecto de validade desaparece, por vezes, em várias abordagens típicas das ciências da religião, por exemplo em formulações importantes da psicologia da

\footnotetext{
${ }^{47} \mathrm{E}$, às vezes, também a partir de uma abordagem teológica, por exemplo quando o conceito de religião se torna definitivo, antepondo-se, em concorrência, a outras definições do objeto teológico, como soem ser "fé" ou "revelação".

${ }^{48}$ LÖFFLER, Einführung in die Religionsphilosophie, p. 11-12, 13-14.

${ }^{49}$ SMITH, Jonathan Z. Religion, Religions, Religious, p. 281. Evidentemente, Smith deixa de considerar a possibilidade um tipo intermediário, a saber, o que entenderia "antropologia" e "antropológico" já não no sentido simplesmente antropológico-cultural, mas antropológico-filosófico. A idéia de que a religião seria algo como uma constante antropológica universal, dirigida a uma dimensão transcendente, foi afirmada p. ex. por Schleiermacher, e criticada não só a partir das teses mais contemporâneas da secularização, mas também (implicitamente) pela filosofia da religião de L. Feuerbach, que colocou as bases para boa parte da leitura do "fato religioso" como projeção. CRUZ, A persistência dos deuses, p. ex. p. 71, parece apontar também para novas formulações da tese da religião como constante antropológica universal, embora o faça amparado nas ciências da natureza (biologia), e lendo Feuerbach já positivamente, evitando o reducionismo antropológico por uma restrição metodológica à sua metafísica (em Feuerbach, normalmente, "materialismo antropológico"). Para uma tentativa de assinalar a diferença fundamental entre Schleiermacher e Feuerbach, e para a defesa "protofenomenológica" da intencionalidade religiosa em Schleiermacher, cf. WILLIAMS, Robert R. Schleiermacher and Feuerbach on the Intentionality of Religious Consciousness. The Journal of Religion, v. 53, 1973, p. 425-55. (Cf. tb. n. 33 acima.)
} 
religião $^{50}$, mas arguivelmente não só nelas, e não só nesta disciplina. Fundamental para uma consideração da validade da religião é a distinção filosófica entre questões de origem e questões de verdade na religião: segundo ela, as ofertas de explicação sobre a origem empírica da religião não resolvem, ainda, a questão de sua validade e/ou pretensão de verdade. Uma das maneiras de considerar justamente tal pretensão seria procurar entender a religião como uma proposta de crença e vida que comporta alguma forma de racionalidade, ou que deve ser levada a sério em sua pretensão de ser, não em cada detalhe ou asserção, mas em suas mais importantes e invariáveis feições, uma forma de "explicação do mundo" ao lado de outras formas, como a ciência, por exemplo. ${ }^{51}$

Last but not least, e ligado ao que justamente acabou de ser dito, esteve subterraneamente presente - ou às vezes nem tanto -, em toda a exposição anterior, a questão relativa à pretensão que num sentido puramente formal une a religião, a filosofia e as ciências em geral de serem modos de explicação do mundo num sentido mais forte da palavra. A filosofia da religião pode naturalmente tomar a peito apenas a tarefa, já em si imensa, de elucidar as estruturas universais da experiência religiosa, sua essência e sua validade. Pode também averiguar os pressupostos gnosiológicos e metafísicos dos conceitos operacionais e especialmente definitivos, explícitos ou não, de religião vigentes nas várias ciências da religião. Mas somente esta tarefa pode, em dadas situações, e na dependência de gosto, convicção e temperamento, não lhe bastar. Como a teologia, a filosofia ocupa-se igualmente do conceito e da verdade da religião, e dependendo de como se leve a cabo esta ocupação, a atividade pode implicar o que chamarei, cuidadosamente, de construção especulativa ou oferta cosmovisiva. ${ }^{52}$

Ofertas cosmovisivas, desde o declínio da centralidade da atividade filosófica no Ocidente moderno, são igualmente feitas pelas ciências, e ultimamente, de modo de novo mais intenso, pelas religiões. ${ }^{53}$ No que tange às primeiras, e sobretudo às ciências humanas e sociais - incluindo-se aí a psicologia - seria ingenuidade crer que estão isentas desta tentação. A verdade é que onde há subjetividade, parece sempre haver também algum tipo de "instinto metafísico" ou metafísico-religioso que não se contenta

\footnotetext{
${ }^{50}$ LÖFFLER, Einführung in die Religionsphilosophie, p. 21, cita a abordagem de C. G. Jung; para ela, segundo o autor, “'na verdade' a religião fala somente de relações psíquicas".

${ }^{51}$ LÖFFLER, Einführung in die Religionsphilosophie, p. 26-27, visualiza tipos de filosofia da religião em estreita correspondência com estas tarefas.

52 Evidentemente, não poucos filósofos resistem à idéia de entender a filosofia como oferta cosmovisiva, por temor, não raro justificado, de que a filosofia perca seu viés crítico. A ênfase no aspecto puramente reflexivo da filosofia, na filosofia como atividade de constante questionamento, ao invés de nela como teoria já objetivada e neste sentido em algum sentido "dogmática", dirige-se contra a tendência a constituir visão de mundo da qual tampouco a filosofia está isenta. (Diga-se de passagem, e em certa relação com isso, que infelizmente, e em casos extremos mas mais comuns do que se imagina, professores de filosofia por vezes conseguem mediocrizar os estudantes mais desavisados, que, sem a leitura cuidadosa dos esforços sistemáticos nos clássicos da história da filosofia, aprendem a questionar tudo e nunca constroem nada. É, sabidamente, sempre mais fácil fazer isso, que é quase nada.) Seja como for: sinto-me inclinado a pensar que a possível perda de viés crítico da filosofia não está intrinsecamente ligada à sua antiquíssima tendência a constituir visão de mundo; e que a associação factual entre ambas, embora possa ser freqüente, é contingente, e não necessária.

53 SMITH, Religion, Religions, Religious, p. 281, aponta para a definição não-antropológica de religião de Ninian Smart, que a entende justamente como "cosmovisão" ou "visão de mundo".
} 
com os achados da ciência, a qual nunca é totalmente pura, por ser sempre, também, uma empresa humana. Mesmo enfoques que incluem alguma forma de empirismo, naturalismo, relativismo ou objetivismo não estão isentos deste instinto; de fato, mesmo quando negado, ele por vezes inclusive se vinga na esfera privada das crenças injustificáveis, formando mais de um "pagão com a razão e cristão - ou qualquer outro crente! - com o coração". Aliás, todos os conceitos recém mencionados - que nem sempre são apenas chavões gastos - são velhos conhecidos da filosofia, e todos eles estão eivados de pressupostos que precisariam ainda justificar-se, a menos que confessem, os que os aplicam, que em tudo, também nas tarefas intelectuais, trata-se em última análise de poder, ou seja, de quem vence no fim do dia, e não de validade e de reconhecimento. Mas esta seria, mais cedo ou mais tarde, não mais que uma vitória de Pirro, e a própria morte anunciada das ciências.

\section{Referências}

BRANDT, Hermann. As ciências da religião numa perspectiva intercultural: a percepção oposta da fenomenologia da religião no Brasil e na Alemanha. Estudos Teológicos, v. 46, n.1, São Leopoldo, 2006, p. 122-51.

CAYGILL, Howard. Dicionário Kant. Trad. Álvaro Cabral. Rio de Janeiro: Jorge Zahar, 2000. [1995.]

CRUZ, Eduardo R. A persistência dos deuses: religião, cultura e natureza. São Paulo: UNESP, 2004.

DREHER, Luís H. Ciência(s) da Religião: Teoria e Pós-Graduação no Brasil. In: Faustino TEIXEIRA (Ed.). A(s) ciência(s) da religião: afirmação de uma área acadêmica. São Paulo: Paulinas, 2001, p. 151-78.

KODALLE, Klaus-M., KÜHNLEIN, Michael. Religionsphilosophie. In: PIEPER, Annemarie (Ed.). Philosophische Disziplinen: Ein Handbuch. Leipzig: Reclam, 1998, p. 343-67.

LAUER, Quentin. Phenomenology: Its Genesis and Prospect. New York: Harper \& Row, 1965 [1958].

LÖFFLER, Winfried. Einführung in die Religionsphilosophie. Darmstadt: Wissenschaftliche Buchgesellschaft, 2006. (Einführungen Philosophie.)

MARQUES, Ângela Cristina Borges, ROCHA, Marcelo. Memórias da fase inicial da Ciência da Religião no Brasil - Entrevistas com Edênio Valle, José J. Queiroz e Antonio Gouvêa Mendonça, Rever: Revista de Estudos da Religião, n. 1, 2007, p. 192214. 
NYGREN, Anders. Religious Apriori. Trad. Kjell O. Lejon. Linköping: Linköping University Electronic Press, 2000 [1921]. (Linköping Studies in Religion and Religious Education, n. 2.)

OTTO, Rudolf. O Sagrado. Trad. João Gama. Lisboa: Edições 70, 1992. [1917.]

RICHTER, L. Religiöses Erlebnis. In: Die Religion in Geschichte und Gegenwart $(=R G G)$, 3. ed. Tübingen, J.C.B. Mohr (Paul Siebeck), 1956-1965, v. 2, p. 569-72.

SCHAEFFLER, Richard. Filosofia da Religião. Trad. Artur Morão. Lisboa: Edições 70, 1992.

SCHULZ, W. Metaphysik. In: Die Religion in Geschichte und Gegenwart ( $=R G G)$, 3. ed. Tübingen, J.C.B. Mohr (Paul Siebeck), 1956-1965, v. 4, p. 908-913.

SMITH, Jonathan Z. Religion, Religions, Religious. In: Mark C. TAYLOR (Ed.). Critical Terms for Religious Studies. Chicago: University of Chicago Press, 1998, p. 269-84.

TILLICH, Paul. Filosofía de la religión. Buenos Aires: Ediciones Megápolis, 1973.

USARSKI, Frank. Constituintes da ciência da religião: cinco ensaios em prol de uma disciplina autônoma. São Paulo: Paulinas, 2006.

WILLIAMS, Robert R. Schleiermacher and Feuerbach on the Intentionality of Religious Consciousness. The Journal of Religion, v. 53, 1973, p. 425-55.

Submetido em: 25-1-2022

Aceito em: 12-2-2022 